\title{
A Long-Lasting Calcium-Activated Nonselective Cationic Current Is Generated by Synaptic Stimulation or Exogenous Activation of Group I Metabotropic Glutamate Receptors in CA1 Pyramidal Neurons
}

\author{
Patrice Congar, Xavier Leinekugel, Yehezkel Ben-Ari, and Valérie Crépel \\ Université René Descartes and Institut National de la Santé et de la Recherche Médicale Unité 29, \\ 75674 Paris Cedex 14, France
}

\begin{abstract}
We have shown previously that a selective metabotropic glutamate receptor (mGluR) agonist, 1S,3R-1-aminocyclopentane-1,3-dicarboxylate (1S,3R-ACPD), evokes an inward current in CA1 pyramidal neurons of rat hippocampal slices in the presence of $\mathrm{K}^{+}$channel blockers (Crépel et al., 1994). This current has been characterized as a $\mathrm{Ca}^{2+}$-activated nonselective cationic (CAN) current. Using whole-cell patch-clamp recordings and intracellular dialysis, we now have identified the mGluR subtype and the mechanisms underlying the CAN current $\left(I_{\text {CAN }}\right)$ and report for the first time the presence of a synaptic $I_{\text {CAN }}$ in the mammalian CNS. First, we have shown pharmacologically that activation of $I_{\text {CAN }}$ by $1 S, 3 R$-ACPD involves the group I mGluRs (and not the groups II and III) and a G-protein-dependent process. We also report that $I_{\mathrm{CAN}}$ is modulated by the divalent cations $\left(\mathrm{Mg}^{2+}, \mathrm{Cd}^{2+}\right.$, and $\left.\mathrm{Zn}^{2+}\right)$. Second, we have isolated a slow synaptic inward current evoked by
\end{abstract}

a high-frequency stimulation in the presence of $\mathrm{K}^{+}$channel blockers, ionotropic glutamate, and $\mathrm{GABA}_{\mathrm{A}}$ receptor antagonists. This current shows similar properties to the exogenously evoked $I_{\text {CAN }}$ : its reversal potential is close to the reversal potential of the $1 S, 3 R$-ACPD-evoked $I_{\text {CAN }}$, and it is G-protein- and $\mathrm{Ca}^{2+}$-dependent. Because the amplitude and duration of $I_{\text {CAN }}$ increased in the presence of a glutamate uptake blocker, we suggest that this synaptic current is generated via the activation of mGluRs. We propose that the synaptic $I_{\text {CAN }}$, activated by a brief tetanic stimulation and leading to a long-lasting inward current, may be involved in neuronal plasticity and synchronized network-driven oscillations.

Key words: $\mathrm{Ca}^{2+}$-activated nonselective cationic current; slow synaptic inward current; postsynaptic mGluRs; intracellular perfusion; whole-cell voltage clamp; CA1 pyramidal neurons; hippocampus
Metabotropic glutamate receptors (mGluRs; Sugiyama et al., 1987) form a heterogenous family of G-protein-coupled receptors, which play a crucial role in controlling the cell excitability in the CNS. Multiple physiological roles for mGluRs have been identified, including neuronal excitation (increase of cell excitability, potentiation of glutamate release, coinduction, or facilitation of LTP) as well as neuronal inhibition (hyperpolarization, presynaptic inhibition of glutamate and GABA release, coinduction, or facilitation of LTD), and a possible implication in glutamate-induced neurotoxicity (for review, see Schoepp and Conn, 1993; Gallagher et al., 1994; Ben-Ari and Aniksztejn, 1995; Pin and Duvoisin, 1995). The mGluRs are coupled to a large variety of second messenger systems [including activation of phospholipase C (PLC) and inhibition of adenylyl cyclase] and modulate several ligand-gated ionic channels (for review, see Schoepp and Conn, 1993; Pin and Duvoisin, 1995).

In a previous report, using intracellular recordings, we showed that, in the presence of $\mathrm{K}^{+}$channel blockers, ionotropic gluta-

\footnotetext{
Received Feb. 18, 1997; revised April 16, 1997; accepted April 24, 1997.

Financial support from Institut National de la Santé et de la Recherche Médicale, Centre National pour la Recherche Scientifique, and Direction des Recherches, Etudes et Techniques, is acknowledged. We are grateful to Dr. K. Schimamoto for her generous gift of $\left(2 S, 1^{\prime} R, 2^{\prime} R, 3^{\prime} R\right)$-2-(2,3-dicarboxycyclopropyl) glycine and to Drs. H. McLean, C. Hammond, S. Williams, and D. D. Fraser for their helpful comments and discussions.

Correspondence should be addressed to Dr. Patrice Congar, Institut National de la Santé et de la Recherche Médicale Unité 29, 123 Boulevard de Port Royal, 75674 Paris Cedex 14, France.

Copyright (C) 1997 Society for Neuroscience $\quad 0270-6474 / 97 / 175366-14 \$ 05.00 / 0$
}

mate, and $\mathrm{GABA}_{\mathrm{A}}$ receptor antagonists, the selective mGluR agonist $1 S, 3 R$-1-aminocyclopentane-1,3-dicarboxylate $\quad(1 S, 3 R$ ACPD) evoked an inward current in CA1 pyramidal neurons of the rat hippocampus (Crépel et al., 1994). This current was characterized as a $\mathrm{Ca}^{2+}$-activated nonselective cationic current (CAN current) on the basis of its ionic properties and its blockade by intracellular injection of the $\mathrm{Ca}^{2+}$ chelating agent BAPTA. However, several questions remain unanswered. (1) Does the link between mGluRs and CAN current involve G-proteins? (2) What types of mGluRs are implicated in the activation of this CAN current (and consequently, which second messenger pathway)? (3) Can this current be activated synaptically?

We now have used whole-cell patch-clamp recordings and intracellular dialysis to study the properties of $I_{\mathrm{CAN}}$. Our observations show that (1) $I_{\mathrm{CAN}}$ is activated by group I mGluRs via a G-protein- and $\mathrm{Ca}^{2+}$-dependent pathway, (2) $I_{\mathrm{CAN}}$ is modulated by divalent cations, and (3) a high-frequency stimulation (HFS) synaptically generates a slow inward current through mGluRs, once glutamate and GABA ionotropic receptors have been blocked. This synaptic current demonstrates features specific to the CAN current; in particular, it is calcium-dependent (blocked by BAPTA) and G-protein-dependent (blocked by G-proteins inhibitors). Therefore, in CA1 pyramidal neurons, in addition to the well characterized fast excitatory currents resulting from the activation of ionotropic AMPA and NMDA receptors, brief tetani generate, via the activation of mGluRs, a long-lasting CAN current. Because of its unique features $I_{\mathrm{CAN}}$ may play a major role 
in neuronal plasticity and network-driven oscillations in neurons of the mammalians CNS.

\section{MATERIALS AND METHODS}

Hippocampal slices preparation. Experiments were performed in CA1 hippocampal neurons in slices obtained from 100-150 gm male Wistar rats (20-40 d old). Rats were anesthetized with ether and decapitated. After decapitation, the brain was removed quickly from the skull, and hippocampi were dissected free on ice in a $0-5^{\circ} \mathrm{C}$ oxygenated artificial cerebrospinal fluid (ACSF) containing (in $\mathrm{mM}$ ): $126 \mathrm{NaCl}, 3.5 \mathrm{KCl}, 1$ $\mathrm{CaCl}_{2}, 2 \mathrm{MgCl}_{2}, 1.2 \mathrm{NaH}_{2} \mathrm{PO}_{4}, 25 \mathrm{NaHCO}_{3}$, and 11 glucose, equilibrated with $95 \% \mathrm{O}_{2} / 5 \% \mathrm{CO}_{2}, \mathrm{pH} 7.4$. Transverse slices (500 $\left.\mu \mathrm{M}\right)$ were prepared with a MacIlwain tissue chopper and were incubated in ACSF at room temperature, as previously described (Cherubini et al., 1987). After a $2 \mathrm{hr}$ recovery period, hippocampal slices were transferred one at a time to a submerged recording chamber and superfused continuously $\left(2.5-3 \mathrm{ml} / \mathrm{min}\right.$ at $28-30^{\circ} \mathrm{C}$ ) with a phosphate-free ACSF (P-free ACSF). The superfusing ACSF did not contain $\mathrm{NaH}_{2} \mathrm{PO}_{4}$ to avoid precipitation in the following conditions: (1) in the presence of the $\mathrm{K}^{+}$channel blockers TEA (5-25 mM) and 4-AP (5 mM), (2) when the external $\mathrm{Mg}^{2+}$ concentration was raised (from 2 to $10 \mathrm{mM})$, or (3) when $\mathrm{Cd}^{2+}(200 \mu \mathrm{M})$ or $\mathrm{Zn}^{2+}(200 \mu \mathrm{M})$ was added.

Whole-cell patch-clamp recordings. Whole-cell patch-clamp recordings were obtained from CA1 pyramidal neurons by using the "blind" patchclamp technique. Membrane currents were recorded in the voltage-clamp mode with an Axopatch 200A amplifier (Axon Instruments, Foster City, CA). Patch electrodes were pulled from borosilicate thin-wall glass capillaries (GC150F-15, Clarck Electromedical Instruments, Pangbourne, UK) with a vertical puller (Glass Microelectrodes Puller PP83, Narishige, London, UK). Broad taper pipettes were used to optimize the solution exchange at their tips. These pipettes had a resistance of 5-7 M $\Omega$ when filled with a $\mathrm{Cs}$ gluconate (CsGlu) internal solution that contained (in mM): 120 CsGlu, $10 \mathrm{CsCl}, 10 \mathrm{NaCl}, 1 \mathrm{CaCl}_{2}, 2 \mathrm{MgATP}, 0.5 \mathrm{GTP}, 10$ EGTA, and 10 HEPES, pH 7.25 (intracellular-free $\mathrm{Ca}^{2+} \approx 100 \mathrm{nM}$ ). In some experiments CsGlu was substituted for equimolar Cs chloride $(\mathrm{CsCl})$. Resting membrane potential was estimated from the potential observed on withdrawal of the electrode from the cell. Holding potential was maintained at $-60 \mathrm{mV}$ for all cells recorded. Membrane input conductance was monitored by application of hyperpolarizing voltage steps of $10 \mathrm{mV}(0.03 \mathrm{~Hz})$ throughout the experiments. Cells showing changes in intrinsic membrane input resistance during the experiments were discarded.

In all experiments, except during synaptic recordings (see below), $1 \mu \mathrm{M}$ tetrodotoxin (TTX) and $50 \mu \mathrm{M}$ methoxyverapamil (D600), $10 \mu \mathrm{M}$ bicuculline, and $1 \mathrm{~mm}$ kynurenate were present in the P-free ACSF to inhibit $\mathrm{Na}^{+}$and voltage-dependent $\mathrm{Ca}^{2+}$ currents, respectively, and to antagonize $\mathrm{GABA}_{\mathrm{A}}$, AMPA, and NMDA receptor-mediated currents, respectively. In these experiments $\mathrm{K}^{+}$currents were suppressed by concomitant intracellular perfusion of CsGlu-containing pipette solution and by the addition of $6 \mathrm{~mm} \mathrm{CsCl}$ (to depress $I_{\mathrm{O}}$ ), 5-25 mM tetraethylammonium chloride (TEACl; to depress $I_{\mathrm{M}}, I_{\mathrm{K}}$, and the fast $\mathrm{Ca}^{2+}$-dependent $\mathrm{K}^{+}$ current $I_{\mathrm{C}}$ ), and $5 \mathrm{~mm}$ 4-aminopyridine (4-AP; to block the early fastinactivating $I_{\mathrm{A}}$ and the slow-inactivating $I_{\mathrm{D}}$ currents) to the P-free ACSF (Segal and Barker, 1984; Storm, 1988, 1990). This superfusing medium was called medium A. The glutamatergic [ $200 \mu \mathrm{M} 1 S, 3 R$-ACPD, $200 \mu \mathrm{M}$ 3,5-dihydroxyphenylglycine (DHPG), $10 \mu \mathrm{M}$ (2S,1' $\left.R, 2^{\prime} R, 3^{\prime} R\right)-2-(2,3-$ dicarboxycyclopropyl) glycine (DCG IV), and $1 \mathrm{mM} \mathrm{L-2-amino-4-}$ phosphonobutyrate (L-AP4)] or muscarinic (60-120 $\mu \mathrm{M}$ carbachol) metabotropic receptor agonists, the glutamatergic [1 mM $(S)-\alpha$-methyl4-carboxyphenylglycine $(S)-\mathrm{MCPG}]$ or muscarinic (10 $\mu \mathrm{M}$ atropine) metabotropic receptor antagonists, and the activator of adenylyl cyclase $(50 \mu \mathrm{M}$ forskolin) or the glutamate uptake inhibitor dihydrokainic acid (DHK; 250-500 $\mu \mathrm{M}$ ) were dissolved in this medium A and were bathapplied. The voltage dependence of these metabotropic receptorinduced currents was studied using ( +50 to $-100 \mathrm{mV}, 8 \mathrm{sec}$ ) ramp voltage commands: the membrane potential was stepped from $V_{\mathrm{H}}$ to +50 $\mathrm{mV}$, held at $+50 \mathrm{mV}$ for $500 \mathrm{msec}$, and then ramped to $-100 \mathrm{mV}$ in 7.5 $\sec (\operatorname{ramp} A)$.

Synaptic recordings were performed with recording pipettes containing $2 \mathrm{mM}$ of $\mathrm{N}$-(2,6-dimethylphenylcarbamoylmethyl) triethylammonium bromide (QX 314; diluted into the CsGlu solution) to block $\mathrm{Na}^{+}$voltagedependent channels. In these experiments the superfusing medium contained $20 \mu \mathrm{M}$ bicuculline, $40 \mu \mathrm{M}$ CNQX, $200 \mu \mathrm{M}$ DL-2-amino-5-

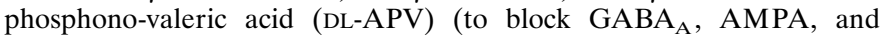
NMDA receptor-mediated currents, respectively), $\mathrm{K}^{+}$channel blockers
(5-25 mM TEA, $5 \mathrm{~mm}$ 4-AP, and $6 \mathrm{mM} \mathrm{Cs}^{+}$), and $1 \mathrm{mM} \mathrm{Mg}^{2+}$ (medium B). The voltage dependence of the synaptically evoked current was studied using $(-20 \mathrm{mV}$ to $-100 \mathrm{mV}, 1 \mathrm{sec})$ ramp voltage commands: the membrane potential was stepped from $V_{\mathrm{H}}$ to $-20 \mathrm{mV}$, held at $-20 \mathrm{mV}$ for $100 \mathrm{msec}$, and then ramped to $-100 \mathrm{mV}$ in $1 \mathrm{sec}$ (ramp B).

Pipette-whole-cell perfusion. Experiments requiring intracellular perfusion were performed with a $2 \mathrm{PK}^{+}$pipette-whole-cell perfusion kit combined with an MRC-6 multireservoir carrousel (ALA Scientific Instruments, Rockville Center, NY). The reservoirs contained various intracellular solutions (drugs were diluted to their final concentration in the CsGlu pipette solution) and were connected to a common pressure vessel. The outlet from the vessel was fed into a valve, and a thin polyethylene tube (PE 10) connected to the output of this valve was inserted into the recording pipette through the perfusion port of a specific pipette holder. The polyethylene tube ended by a connection to a polyimide-coated quartz microperfusion capillary, thinned down at the other end by a high flame pulling (cleaned and cut for a final tip size of $30-50 \mu \mathrm{M}$ ), extending close to the tip of the recording pipette in a position in which its orifice was approximately one-half of the internal diameter of the pipette. The inlet to the pressure vessel was fed into a valve and connected to a pressure/vacuum generator. Pipette-whole-cell perfusion was achieved by two successive 5 min periods of active perfusion (application of a well defined positive pressure on the inlet to the positive pressure vessel and a conversely negative pressure on the suction port of the pipette holder, both simultaneously generated by the pressure/ vacuum generator), interspersed by $5 \mathrm{~min}$ of passive diff usion.

Fluorescence measurements. Fluorescence measurements were performed as previously described (Leinekugel et al., 1995) on neurons loaded with the $\mathrm{Ca}^{2+}$-sensitive dye Fluo-3 in the impermeant form (whole-cell configuration CsGlu pipette solution containing $0.01 \mathrm{~mm}$ Fluo-3), using a confocal laser scanning microscope (MRC Bio-Rad 600, Munich, Germany) equipped with an argon-krypton laser and photomultiplier. Excitation was delivered at $488 \mathrm{~nm}$, and emission intensity was measured at wavelengths $>500 \mathrm{~nm}$. Images were acquired every 10 sec with the program SOM (Bio-Rad) and analyzed off-line with the program Fluo (Imstar, Paris, France). All results were expressed as $\Delta F / F_{0}$, with $F$ equal to fluorescence from the defined portion of the image corresponding to the cell under investigation and $F_{0}$ equal to the mean base line fluorescence in the selected area from at least five consecutive images. Because Fluo-3 is a single wavelength chromophore and fluorescence is a function of the concentration of $\mathrm{Ca}^{2+}$ and dye (Kao et al., 1989), we have used this dye only for an approximate estimation of $\left[\mathrm{Ca}^{2+}\right]_{i}$ and included for analysis only experiments in which the fluorescence level recovered to control value after cell excitation. As described earlier (Leinekugel et al., 1995), individual neurons were selected by using the optics of an Axioscope Karl Zeiss microscope (water immersion objective $40 \times$ ) that allows recognition of pyramidal neurons in slices.

Materials. DCG IV was generously supplied by Dr. K. Shimamoto (Suntori Institute for Bio-organic Research, Osaka, Japan). DHPG, L-AP4, [( $S)$-MCPG], 1S,3R-ACPD, bicuculline, 6-cyano-7-nitroquinoxaline-2,3-dione (CNQX), and DL-APV were purchased from Tocris Cookson (Bristol, UK). Fluo-3 was purchased from Molecular Probes (Eugene, OR). Kynurenate and all other drugs were purchased from Sigma (St. Louis, MO).

Data analysis. Membrane responses were digitized and displayed simultaneously on a Nicolet digital oscilloscope and on a computer-driven chart recorder. Data were analyzed off-line on computer (programs G, Sadoc, France) and are presented as means \pm SEM. Statistical significance $(p \leq 0.05)$ was assessed by the Student's $t$ test analysis (paired data).

\section{RESULTS}

Experiments were performed on a homogenous population of 78 pyramidal cells of the CA1 hippocampal region. On average, resting membrane potential was $-62 \pm 0.5 \mathrm{mV}$, and input resistance was $173 \pm 5.7 \mathrm{M} \Omega$.

\section{In the presence of $\mathrm{K}^{+}$channel blockers, 1S,3R-ACPD induced a $\mathrm{Ca}^{2+}$-activated nonselective cationic current: $I_{\text {CAN }}$}

As previously shown with intracellular recordings (Crépel et al., 1994), with continual application of $\mathrm{K}^{+}$channel blockers (5-25 


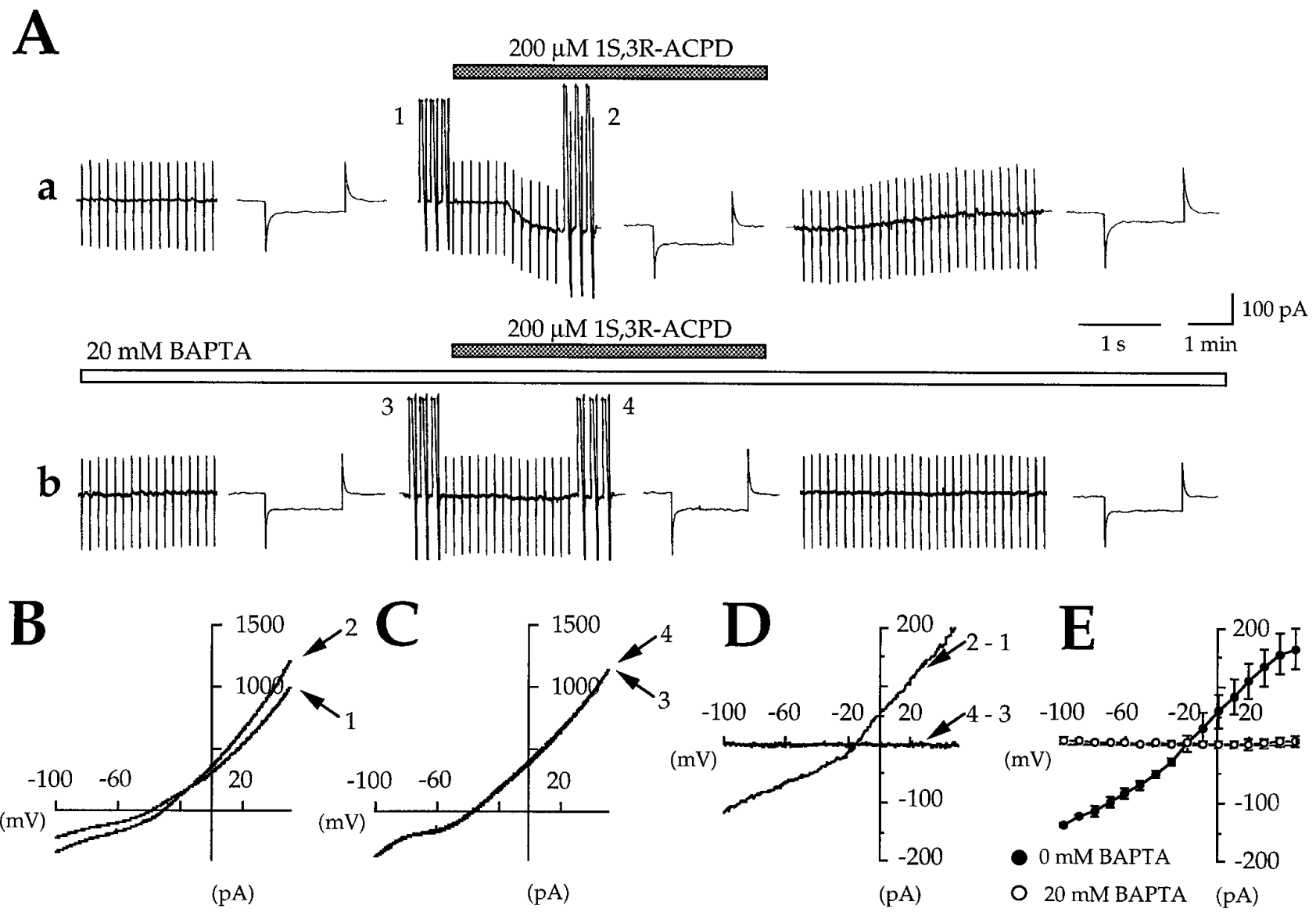

Figure 1. In the presence of $\mathrm{K}^{+}$channel blockers, $1 S, 3 R$-ACPD induced a $\mathrm{Ca}^{2+}$-activated nonselective cationic current, $I_{\mathrm{CAN}}$. In control conditions $1 S, 3 R$-ACPD activates an inward current $\left(I_{\mathrm{ACPD}}\right)$ with a reversal potential close to that of a nonselective cationic current. Whole-cell perfusion of the calcium chelator BAPTA prevents activation of $I_{\mathrm{ACPD}} \cdot A$ - $a$, Membrane current and conductance changes evoked by $1 S, 3 R$-ACPD $\left(200 \mu \mathrm{M}, 2\right.$ min, $V_{\mathrm{H}}$ $=-60 \mathrm{mV}$ ) in control conditions recorded (in this and in Figs. 2-7) in the presence of P-free ACSF containing $1 \mu \mathrm{M}$ TTX, $10 \mu \mathrm{M}$ bicuculline, $1 \mathrm{~mm}$ kynurenate, $50 \mu \mathrm{M} \mathrm{D} 600$, and $\mathrm{K}^{+}$channel blockers (5-25 mM TEA, $5 \mathrm{mM} 4-\mathrm{AP}$, and $6 \mathrm{~mm} \mathrm{CsCl}$ ) in patch-clamp whole-cell configuration using CsGlu-containing pipette solution. Hyperpolarizing voltage step of $10 \mathrm{mV}(0.03 \mathrm{~Hz})$ was applied constantly during the experiment. $A-b$, Membrane current and conductance changes evoked in the same cell by $1 S, 3 R$-ACPD (200 $\left.\mu \mathrm{M}, 2 \mathrm{~min}, V_{\mathrm{H}}=-60 \mathrm{mV}\right) 10 \mathrm{~min}$ after pipette-whole-cell perfusion with BAPTA-containing $(20 \mathrm{~mm})$ pipette solution. $B, C$, Individual current-voltage $(I / V)$ relations (ramp command A; see Materials and Methods) obtained at the times indicated by numbers in $A-a$ and $A-b$ in the absence $(B)$ and in the presence $(C)$ of BAPTA. $D, I / V$ relations obtained by subtracting the current traces obtained in the absence $(B)$ and in the presence $(C)$ of BAPTA. $E$, Mean $I / V$ relation of $1 S, 3 R$-ACPD-induced current in the absence and in the presence of intracellular BAPTA $(n=5$; paired data). In this and in all following figures, the error bars represent the SEM.

mM TEA, $5 \mathrm{~mm}$ 4-AP, and $6 \mathrm{~mm} \mathrm{Cs}^{+}$diluted in the superfusing medium A; see Materials and Methods), bath application of $1 S, 3 R$-ACPD (200 $\mu \mathrm{M}, 2 \mathrm{~min})$ evoked a reversible inward current of $-64.4 \pm 3.4 \mathrm{pA}$, peak amplitude at $V_{\mathrm{H}}=-60 \mathrm{mV}\left(I_{\mathrm{ACPD}}\right.$; Fig. $1 A-a)$. This current was associated with a significant increase in membrane conductance of $42.9 \pm 3.4 \%(2.2 \pm 0.1$ and $3.1 \pm 0.1$ $\mathrm{nS}$ in the absence and in the presence of $1 S, 3 R$-ACPD, respectively; $n=55, p=0.0001)$. The voltage dependence of $I_{\mathrm{ACPD}}$ was studied by plotting $I / V$ relations derived from hyperpolarizing ramp commands from +50 to $-100 \mathrm{mV}$ (ramp A; see Materials and Methods). $I_{\mathrm{ACPD}}$ had a reversal potential of $-17 \pm 1.3 \mathrm{mV}$ $(n=55)$, slightly more negative than that predicted by the Nernst equation $(+3.5 \mathrm{mV})$ at the experimental conditions of [cations] $=160.5 \mathrm{~mm}$ and [cations $]_{i}=140 \mathrm{~mm}$ (but see Discussion). The $I / V$ relation of $I_{\mathrm{ACPD}}$, obtained by subtracting the current recorded in the presence of $1 S, 3 R$-ACPD from that recorded in the absence of $1 S, 3 R$-ACPD, was not linear but displayed an area of reduced slope conductance at voltages more negative than $-40 \mathrm{mV}$ (Fig. $1 D, E)$. The conductances calculated for the two representative membrane potential intervals, -100 to $-60 \mathrm{mV}$ (which will be referred to as negative conductance) and 0 to $+40 \mathrm{mV}$ (which will be referred to as positive conductance) were significantly different, $0.92 \pm 0.08$ and $2.1 \pm 0.1 \mathrm{nS}$, respectively $(n=55, p=$ $0.0001)$, showing a negative rectification of $-48 \pm 5.7 \%(n=55)$. These current properties were observed similarly in the presence of CsGlu-containing and CsCl-containing pipette solution (data not shown), confirming the chloride gradient independence of the current.

The dependence of $I_{\mathrm{ACPD}}$ on $\left[\mathrm{Ca}^{2+}\right]_{\mathrm{i}}$ was studied first by recording CA1 pyramidal cells in the whole-cell configuration in the presence of Fluo-3 diluted in the CsGlu pipette solution (see Materials and Methods). Changes of $\left[\mathrm{Ca}^{2+}\right]_{\mathrm{i}}$ were monitored in the soma of pyramidal neurons with a confocal laser scanning microscope simultaneously to the recording of $I_{\mathrm{ACPD}}$ (performed in the presence of the superfusing medium A). As previously described in cultured hippocampal neurons and CA1 pyramidal cells (Mayer and Miller, 1990; Frenguelli et al., 1993; Jaffe and Brown, 1994; Petrozzino and Connor, 1994; Shirasaki et al., 1994), $1 S, 3 R$-ACPD induced a significant rise of $\left[\mathrm{Ca}^{2+}\right]_{\mathrm{i}}$ of $49 \pm$ $14 \%\left(V_{\mathrm{H}}=-60 \mathrm{mV} ; n=4, p<0.05\right)$ (Fig. 2). The increase of 
a

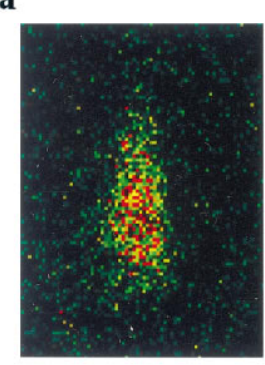

b

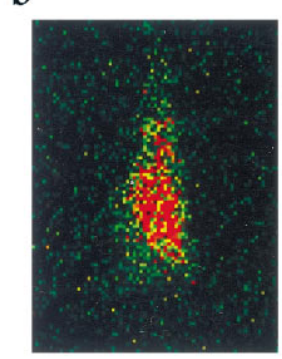

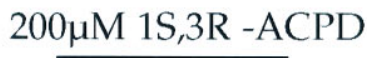
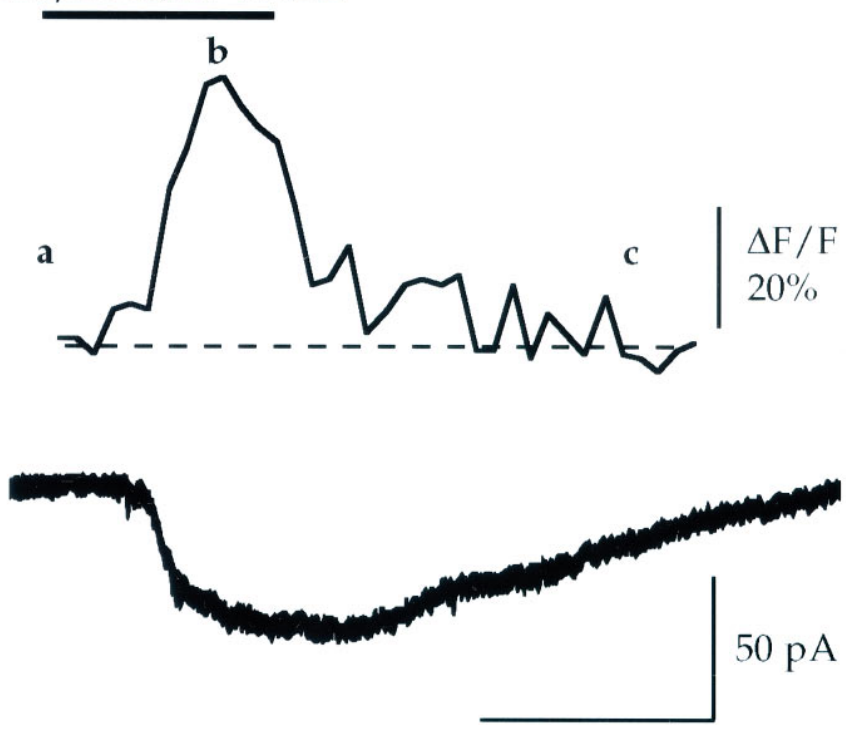

$2 \min$

Figure 2. $I_{\mathrm{ACPD}}$ is associated with an increase in intracellular $\left[\mathrm{Ca}^{2+}\right]$. Changes in intracellular $\left[\mathrm{Ca}^{2+}\right]$ induced by application of $1 S, 3 R$-ACPD were recorded from the soma of CA1 pyramidal neurons loaded in whole-cell configuration with the $\mathrm{Ca}^{2+}$-sensitive dye Fluo-3 $(0.01 \mathrm{~mm}$ diluted in the CsGlu pipette solution). Fluorescence images were acquired every $10 \mathrm{sec} ;\left[\mathrm{Ca}^{2+}\right]_{\mathrm{i}}$ was quantified and correlated to the simultaneously recorded CAN current. Top panels, Successive pseudocolored photomicrographs of the fluorescence collected before $(a)$, during $(b)$, and after $(c)$ application of $1 S, 3 R$-ACPD (200 $\mu \mathrm{M}, 2 \mathrm{~min}, V_{\mathrm{H}}=-60$ $\mathrm{mV}$ ). Middle trace, Mean changes of the $\mathrm{Ca}^{2+}$-dependent fluorescence, observed in four CA1 pyramidal neurons, during the corresponding electrophysiologically recorded $I_{\text {CAN }}$ (bottom trace). Note that the rise in $\left[\mathrm{Ca}^{2+}\right]_{\mathrm{i}}$ is strictly correlated to the rise phase of $I_{\mathrm{CAN}}$.

$\left[\mathrm{Ca}^{2+}\right]_{\mathrm{i}}$ was correlated closely to the $I_{\mathrm{ACPD}}$ simultaneously recorded, and both displayed similar latency $(47.5 \pm 10.3$ and $60 \pm$ $10.8 \mathrm{sec}$, respectively; $n=4, p=0.15)$ and time to peak $(127.5 \pm$ 16 and $136.3 \pm 9 \mathrm{sec}$, respectively; $n=4, p=0.37$ ) (Fig. 2).

To show directly that $I_{\mathrm{ACPD}}$ depends on the rise in $\left[\mathrm{Ca}^{2+}\right]_{\mathrm{i}}$, we used pipette-whole-cell perfusion with the $\mathrm{Ca}^{2+}$ chelating agent BAPTA $(20 \mathrm{~mm})$ diluted in the CsGlu pipette solution. Two series of preliminary experiments were performed to confirm the efficacy of the pipette-whole-cell perfusion system. The first consisted of three successive applications of $1 S, 3 R$-ACPD, one before and two after a perfusion with the same CsGlu pipette solution. We showed that the perfusion system by itself did not change $I_{\mathrm{ACPD}}$ significantly (see Fig. 3 ), which could be evoked by up to six consecutive applications of $1 S, 3 R$-ACPD (data not shown). The second experiment consisted of testing the effects of whole-cell perfusion of BAPTA on the slow afterhyperpolariza-
A $200 \mu \mathrm{M}$ 1S,3R-ACPD
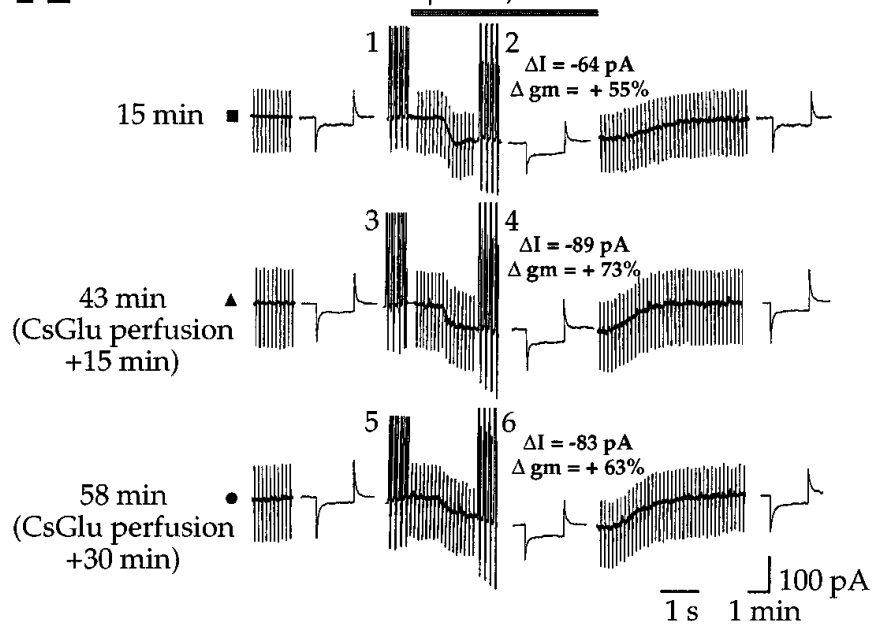

B

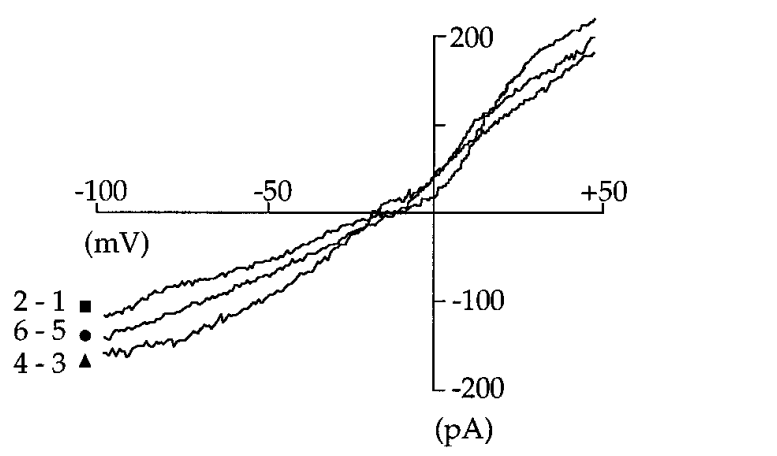

Figure 3. Intracellular perfusion with control CsGlu pipette solution does not modify $I_{\mathrm{CAN}}$. $A$, Membrane currents $(\Delta I)$ and conductance changes $(\Delta \mathrm{gm})$ evoked in the same cell by three successive applications of $1 S, 3 R$-ACPD $\left(200 \mu \mathrm{M}, 2 \mathrm{~min}, V_{\mathrm{H}}=-60 \mathrm{mV}\right)$ in control (口), after $15 \mathrm{~min}$ of cell dialysis with the control CsGlu pipette solution $(\mathbf{\Lambda})$, and after 30 min of cell dialysis with the control CsGlu pipette solution (). Note that the successive applications of $1 S, 3 R$-ACPD induced three similar $I_{\mathrm{CAN}} . B$, $I / V$ relations of the CAN currents induced, in the same cell, by three successive $1 S, 3 R$-ACPD applications and performed, respectively, before $(\boldsymbol{\square}), 15(\mathbf{\Delta})$, and $30 \mathrm{~min}(\bullet)$ after pipette-whole-cell perfusion with control CsGlu pipette solution. These $I / V$ relations have been obtained by subtracting the current traces at the time indicated by the numbers in $A$.

tion (sAHP) after a depolarizing pulse. As previously described with intracellular recordings (Crépel et al., 1994), 10 min after BAPTA perfusion spike frequency accommodation and SAHP disappeared, confirming adequate BAPTA loading (data not shown). In control conditions (before intracellular perfusion of BAPTA), $1 S, 3 R$-ACPD generated a reversible inward current (peak amplitude $=-86.2 \pm 9 \mathrm{pA}$; reversal potential $=-17.6 \pm$ 4.4; $V_{\mathrm{H}}=-60 \mathrm{mV} ; n=5$ ) (Fig. $\left.1 A-a\right)$ associated with an increase in membrane conductance of $51.6 \pm 13 \%(n=5)$. After intracellular BAPTA perfusion (20 mM added to the CsGlu internal solution), subsequent applications of $1 S, 3 R$-ACPD failed to induce inward current (Fig. $1 A-b$ ); under this condition the $1 S, 3 R$ ACPD-mediated current was nearly abolished (the peak amplitude was reduced by $93.7 \pm 2.9 \% ; n=5, p=0.0004$ ) and was not associated with a significant increase in membrane conductance $(0.8 \pm 2.6 \% ; n=5, p=0.004)$. Analysis of the $I / V$ relations (ramp command A) confirm that BAPTA perfusion completely suppressed the $1 S, 3 R$-ACPD-mediated current (Fig. $1 C-E$ ). This showed that $I_{\mathrm{ACPD}}$ is $\mathrm{Ca}^{2+}$-dependent, as previously reported (Crépel et al., 1994). 
A

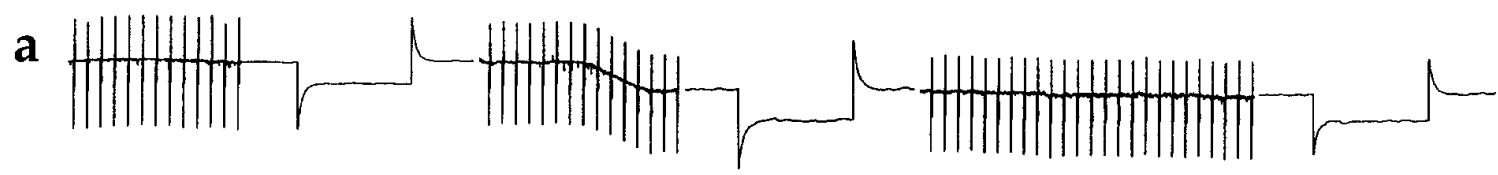

$500 \mu \mathrm{M}$ GTP $\gamma \mathrm{S}$

$200 \mu \mathrm{M}$ 1S,3R-ACPD
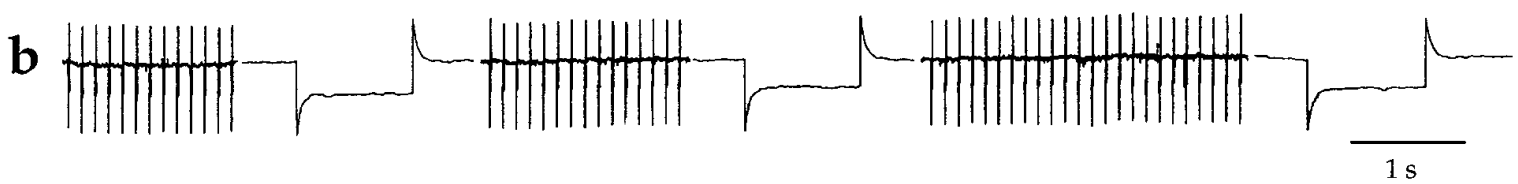
$100 \mathrm{pA}$

B
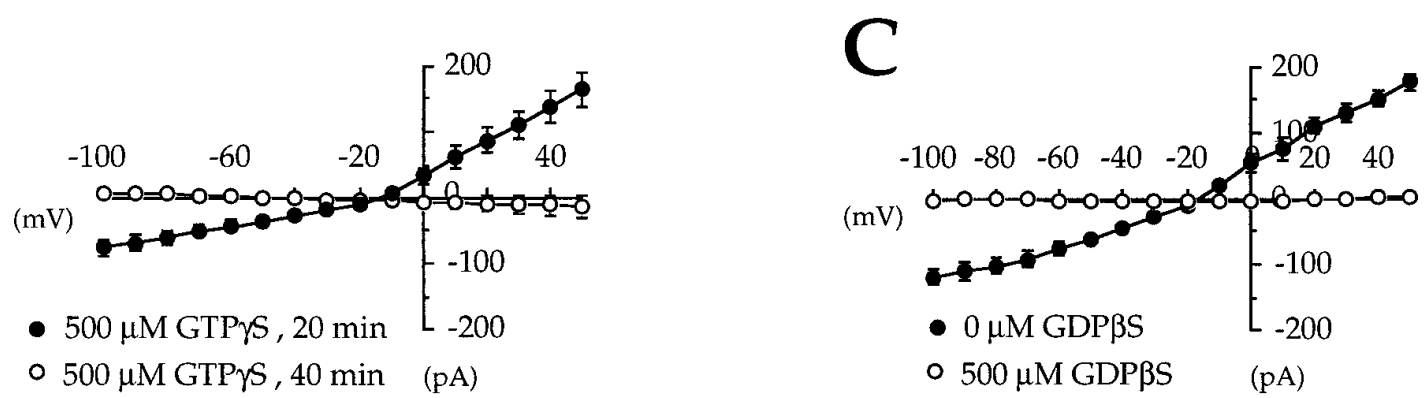

Figure 4. In the presence of the nonhydrolyzable analog of GTP, GTP $\gamma \mathrm{S}, 1 S, 3 R$-ACPD irreversibly activates $I_{\mathrm{CAN}}$, because intracellular perfusion with the G-protein inhibitor GDP $\beta$ S prevents the activation of $I_{\mathrm{CAN}}$. $A$ - $a$, Membrane current and conductance changes evoked by a first application of $1 S, 3 R$-ACPD $\left(200 \mu \mathrm{M}, 2 \mathrm{~min}, V_{\mathrm{H}}=-60 \mathrm{mV}\right)$ after $20 \mathrm{~min}$ of cell dialysis with $500 \mu \mathrm{M}$ GTP $\gamma$ S. Note that $I_{\text {CAN }}$ becomes irreversible in the presence of GTP $\gamma \mathrm{S}$. $A-b$, Membrane current and conductance changes evoked in the same cell by a second application of $1 S, 3 R-\mathrm{ACPD}\left(200 \mu \mathrm{M}, 2 \mathrm{~min}, V_{\mathrm{H}}=-60\right.$ $\mathrm{mV}$ ) after $40 \mathrm{~min}$ of cell dialysis with $500 \mu \mathrm{M}$ GTP $\gamma \mathrm{S}$. Note that, in the presence of GTP $\gamma \mathrm{S}$, a second application of $1 S, 3 R$-ACPD fails to evoke a subsequent response. $B$, Mean $I / V$ relations of the CAN currents obtained in the same cell by two successive $1 S, 3 R$-ACPD applications performed 20 $\min (\bigcirc)$ and $40 \mathrm{~min}(\bigcirc)$, respectively, after cell dialysis with $500 \mu \mathrm{M} \mathrm{GTP} \gamma \mathrm{S}(n=5$; paired data). $C$, Mean $I / V$ relations of the CAN currents obtained by two successive $1 S, 3 R$-ACPD applications in the same cell before $(\bullet)$ and after $(\bigcirc)$ pipette-whole-cell perfusion with $500 \mu \mathrm{M}$ GDP $\beta S(n=7$; paired data).

In conclusion, using whole-cell recordings, we have confirmed that, in the presence of $\mathrm{K}^{+}$channel blockers, $1 S, 3 R$-ACPD induced a current with a reversal potential close to that of a nonselective cationic current, which was triggered by a rise in intracellular $\mathrm{Ca}^{2+}$ concentration. This current will be referred to hereafter as a calcium-activated nonselective cationic current $\left(I_{\mathrm{CAN}}\right)$, as per Crépel et al. (1994); its properties are not modified by whole-cell recordings.

\section{$I_{\text {CAN }}$ is mediated via G-proteins}

To clarify the transduction system leading to an increase in $\left[\mathrm{Ca}^{2+}\right]_{\mathrm{i}}$ required for the activation of the CAN current, we used intracellular dialysis of the specific G-protein inhibitors GTP $\gamma \mathrm{S}$ and GDP $\beta$.

In the first set of experiments we investigated whether $1 S, 3 R$ ACPD still could generate $I_{\text {CAN }}$ when G-proteins were blocked in an activated state. GTP $\gamma \mathrm{S}(500 \mu \mathrm{M})$ was diluted in the GTP-free CsGlu pipette solution to replace GTP at equimolar concentration. In five of five cells, in the presence of GTP $\gamma \mathrm{S}$, the first application of $1 S, 3 R$-ACPD (200 $\mu \mathrm{M}, 2 \mathrm{~min})$ evoked an irreversible $I_{\text {CAN }}$ (peak amplitude $=-47 \pm 5.5 \mathrm{pA}$; reversal potential $=$ $-19 \pm 6.8 \mathrm{mV}$ ) (Fig. $4 A-a$ ); the second application of $1 S, 3 R-$ ACPD failed to evoke any subsequent current, as illustrated in
Figure $4 A-b\left(I_{\mathrm{CAN}}\right.$ was reduced by $98.2 \pm 1.8 \% ; n=5, p=$ 0.0001 ). The analysis of the $I / V$ relations (ramp command A) confirm that GTP $\gamma \mathrm{S}$ completely suppressed the second $1 S, 3 R$ ACPD-mediated current (Fig. 4B).

In the second set of experiments we examined whether $1 S, 3 R$ ACPD could induce $I_{\text {CAN }}$ when G-proteins were blocked in an inactivated state. In this set of experiments GDP $\beta S$ was dialyzed into the cell via the pipette-whole-cell perfusion system; GDP $\beta S$ $(500 \mu \mathrm{M})$ was diluted in the GTP-free CsGlu pipette solution to replace GTP at equimolar concentration. In control conditions, before perfusion of GDP $\beta$ S, a first application of $1 S, 3 R$-ACPD induced the expected fully reversible $I_{\text {CAN }}$ (peak amplitude $=$ $-79.4 \pm 10.9 \mathrm{pA}$; reversal potential $=-16.43 \pm 1.9 \mathrm{mV} ; n=7$ ). In the presence of GDP $\beta$, a subsequent application of $1 S, 3 R$ ACPD failed to induce $I_{\text {CAN }}$ (Fig. $4 C$ ): the second $1 S, 3 R$-ACPDmediated current was nearly abolished (the peak amplitude of $I_{\mathrm{CAN}}$ was reduced by $\left.94.7 \pm 6.4 \% ; n=7, p=0.0007\right)$. The analysis of the $I / V$ relations (ramp command A) confirmed that GDP $\beta$ S completely suppressed the second $1 S, 3 R$-ACPDmediated current (Fig. 4C).

Therefore, $1 S, 3 R$-ACPD activates $I_{\mathrm{CAN}}$ via a G-proteindependent process. 
Table 1. Parameters of the CAN currents evoked in CA1 pyramidal neurons by different metabotropic receptor agonists

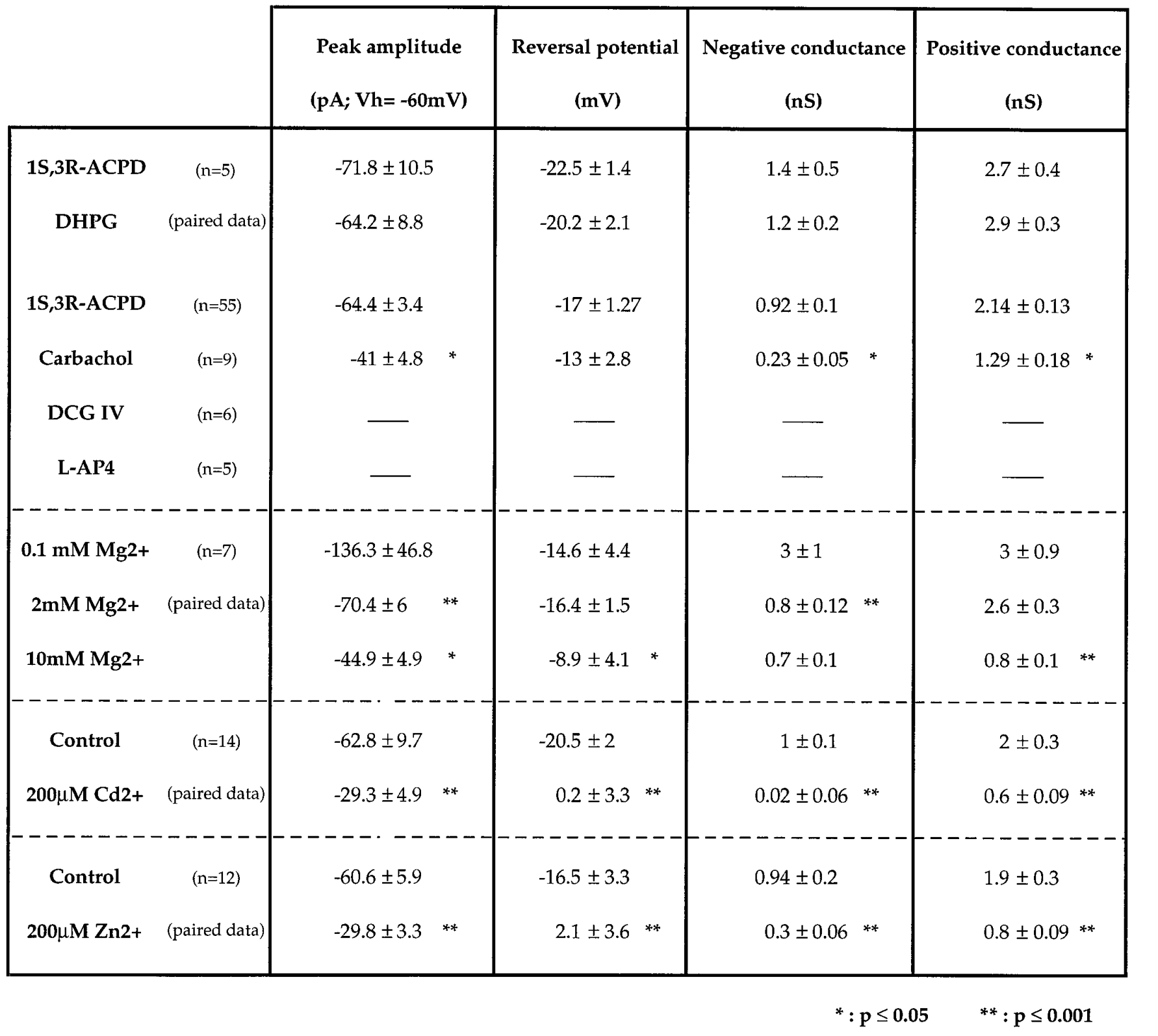

Shown are the effects of extracellular divalent cations in the $1 S, 3 R$-ACPD-induced CAN current.

\section{$I_{\text {CAN }}$ is mediated by group I mGluRs}

Glutamatergic metabotropic receptors are divided into three groups. Group I (including mGluRs 1 and 5) activates PLC [i.e., the inositol triphosphate $\left(\mathrm{IP}_{3}\right)$ production pathway]; group II (including mGluRs 2 and 3 ) and group III (including mGluRs 4, 6,7 , and 8) inhibit adenylyl cyclase (i.e., the cAMP production pathway) (for review, see Schoepp and Conn, 1993; Pin and Duvoisin, 1995). To specify the type of mGluRs involved in the activation of $I_{\mathrm{CAN}}$, we performed pharmacological experiments to test the ability of selective agonists for these three groups to induce $I_{\mathrm{CAN}}$. In each cell in which mGluRs agonists were tested, we subsequently applied $1 S, 3 R$-ACPD (200 $\mu \mathrm{M}, 2 \mathrm{~min})$ to verify the ability of these cells to generate $I_{\mathrm{CAN}}$; only cells that displayed $I_{\mathrm{CAN}}$ were kept for analysis. These data are summarized in Table 1.

Previous immunohistochemical studies have shown that CA1 pyramidal neurons prominently express mGluR5 (Abe et al., 1992; Shigemoto et al., 1993; Luján et al., 1996). Therefore, we first tested the most selective agonist of the group I mGluRs, the DHPG (Ito et al., 1992; Schoepp et al., 1994). With superfusion of medium A (see Materials and Methods), bath application of $200 \mu \mathrm{M}$ DHPG evoked a current identical to that evoked by $1 S, 3 R$-ACPD. The currents evoked by DHPG and $1 S, 3 R$-ACPD had similar peak amplitudes, reversal potentials, and slope conductances; they both exhibited an area of reduced slope conductance at potentials more negative than $-40 \mathrm{mV}$ (see Fig. 5, Table 1). Second, we tested the ability of specific agonists of the group II (DCG IV; Ishida et al., 1993) and the group III (L-AP4; (Thomsen et al., 1992) mGluRs to induce $I_{\text {CAN }}$. Under perfusion with medium A (see Materials and Methods), DCG IV (10 $\mu \mathrm{M}$; $n=6)$ and L-AP4 ( $1 \mathrm{mM} ; n=5)$ were bath-applied for 2-10 min at concentrations 10-50 times higher than their reported $\mathrm{EC}_{50}$ in 
A

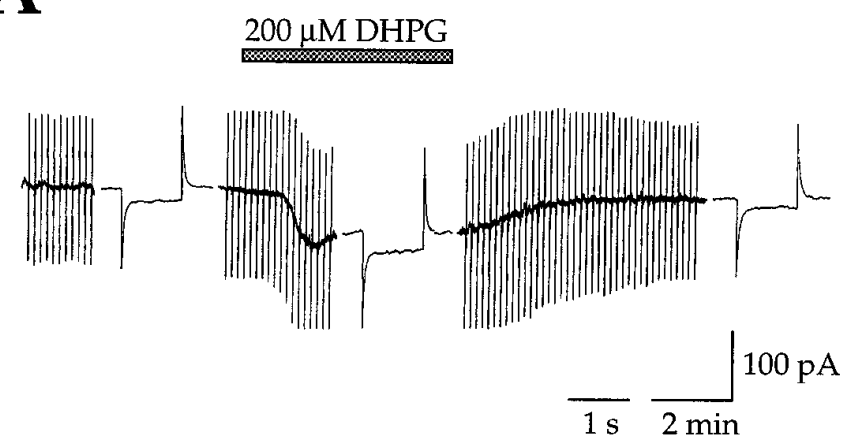

B

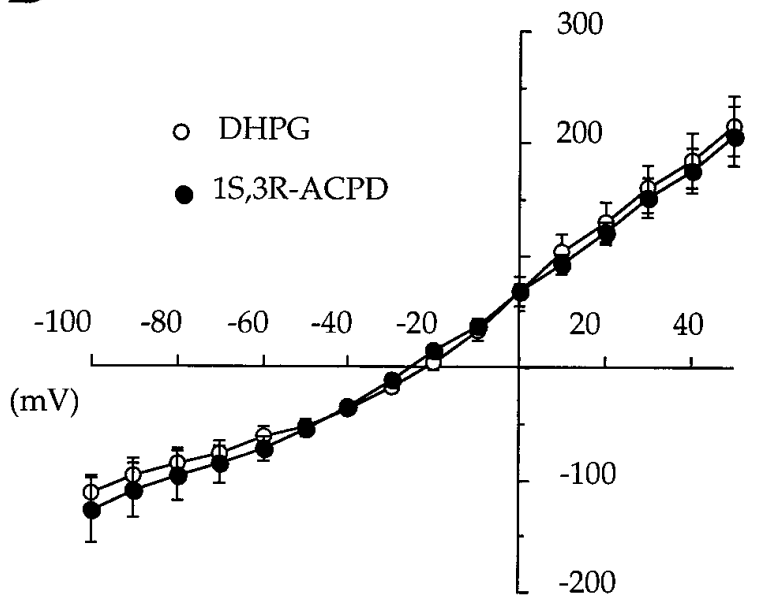

(pA)

Figure 5. The group I mGluRs selective agonist DHPG $(200 \mu \mathrm{M})$ evoked a CAN current identical to that evoked by $1 S, 3 R$-ACPD. $A$, Membrane current and conductance changes evoked by DHPG $\left(200 \mu \mathrm{M}, 2 \mathrm{~min}, V_{\mathrm{H}}=\right.$ $-60 \mathrm{mV}) . B$, Mean $I / V$ relations of DHPG-induced $(O)$ and $1 S, 3 R$-ACPDinduced $(\bullet)$ currents $(n=5$; paired data). Note that $I / V$ relations are very similar (reversal potential, slope conductance; but see also Table 1).

hippocampal slices (Gereau and Conn, 1995). We found that DCG IV and L-AP4 failed to evoke any current (Table 1), whereas in the same cells $1 S, 3 R$-ACPD evoked $I_{\text {CAN }}$ (data not shown).

Finally, we tested the ability of the competitive nonselective mGluR antagonist $(S)$-MCPG (Eaton et al., 1993) to antagonize the DHPG-evoked $I_{\mathrm{CAN}} \cdot(S)$-MCPG $(1 \mathrm{mM} ; n=3)$ was bathapplied after recording a first DHPG-evoked $I_{\mathrm{CAN}}$ in a CA1 pyramidal neuron at least 15-30 min before a second application of DHPG (100-200 $\mu \mathrm{M})$ on the same neuron. ( $S)$-MCPG failed to induce a significant reduction of the DHPG-evoked $I_{\mathrm{CAN}}$, which displayed similar peak amplitudes $(-62.8 \pm 13.6$ and $-68.6 \pm 20.3 \mathrm{pA} ; n=3, p=0.3$ ) and slope conductances (negative conductances: $0.2 \pm 0.47$ and $0.3 \pm 0.7 \mathrm{nS} ; n=3, p=$ 0.35; positive conductances: $2.4 \pm 0.4$ and $1.9 \pm 0.65 \mathrm{nS} ; n=3$, $p=0.11$ ), respectively, in the absence and in the presence of $(S)$-MCPG (data not shown).

These results strongly suggest that $I_{\mathrm{CAN}}$ was evoked by metabotropic receptors positively linked to the $\mathrm{IP}_{3}$ production pathway (i.e., mGluRs of the group I) and not by metabotropic receptors negatively linked to the adenylyl cyclase pathway (i.e., mGluRs of the group II and III). If so, other types of metabotropic receptors linked to the $\mathrm{IP}_{3}$ production pathway (for review, see Schoepp and Conn, 1993) should activate $I_{\mathrm{CAN}}$ also. In keeping with this hypothesis and in agreement with previous data (Shen and North, 1992; Colino and Halliwell, 1993; Fraser and MacVicar, 1996), we found that activation of muscarinic receptors induced a current showing similar features to those of $I_{\mathrm{CAN}}$ : under perfusion with medium A, bath application of 60-120 $\mu \mathrm{M}$ carbachol (a selective agonist of muscarinic receptors linked to $\mathrm{IP}_{3}$ production pathway) (Fisher et al., 1983, 1984; Dutar and Nicoll, 1988) generated a CAN current that was smaller but otherwise comparable to $I_{\text {CAN }}$ induced by $1 S, 3 R$-ACPD $(n=9$; Fig. $6 C$, Table 1$)$. To demonstrate further that $I_{\mathrm{CAN}}$ is not attributable to a change of intracellular cAMP content, we tested the ability of $1 S, 3 R$-ACPD to induce $I_{\mathrm{CAN}}$ in the presence of forskolin, an activator of adenylyl cyclase (which increases the intracellular concentration of cAMP). In this set of experiments $50 \mu \mathrm{M}$ forskolin (diluted in medium A) was bath-applied before (10 min), during ( $2 \mathrm{~min})$, and after $(5 \mathrm{~min})$ the application of $1 S, 3 R$-ACPD $(2 \mathrm{~min}, 200 \mu \mathrm{M})$. First, we observed that forskolin itself did not generate any significant current $(-0.21 \pm 6 \mathrm{pA} ; n=8)$; second, in the presence of forskolin, the current evoked by $1 S, 3 R$-ACPD was not significantly different from that evoked in the absence of forskolin (Fig. $6 A)$ : neither the peak amplitude $(96.5 \pm 27 \%$ of the control; $n=$ $8, p=0.15)$ nor the reversal potential $(-8.5 \pm 3.3$ and $-8.3 \pm 3.7$ $\mathrm{mV}$, respectively, in the presence and in absence of forskolin; $n=$ $8, p=0.3$ ) nor the $I / V$ relation of $I_{\mathrm{CAN}}$ was altered by forskolin (Fig. 6B).

Therefore, in CA1 pyramidal cells the CAN current can be activated by group I mGluRs and muscarinic receptors, which are positively linked to PLC pathway. Our results also demonstrate that the transduction system involved in the activation of $I_{\mathrm{CAN}}$ does not implicate a change of cAMP production.

\section{$I_{\text {CAN }}$ is sensitive to external divalent cations}

As shown in Figures $1-6$, the $I / V$ relation of $I_{\mathrm{CAN}}$ exhibited an area of reduced slope conductance at potentials more negative than $-40 \mathrm{mV}$. We reasoned that this negative rectification could be attributable to a voltage-dependent block by external divalent cations, as has been demonstrated for NMDA channels (Ascher and Nowak, 1988; Mayer et al., 1989) or cyclic nucleotide-gated nonselective channels (for review, see Zufall et al., 1994).

We thus investigated the possible regulatory role of external $\mathrm{Mg}^{2+}$ on $I_{\mathrm{CAN}}$ evoked by $1 S, 3 R$-ACPD in seven cells superfused with medium A containing the following external $\mathrm{Mg}^{2+}$ concentrations: $0.1,2$, and $10 \mathrm{~mm}$. Attempts to investigate effects of medium A containing zero external $\mathrm{Mg}^{2+}$ were abandoned, because we failed to obtain stable long-lasting recordings with such superfusing solution $\left(\mathrm{K}^{+}\right.$channel blockers, low $\mathrm{Ca}^{2+}$, and 0 $\left.\mathrm{Mg}^{2+}\right)$. The results of these experiments are illustrated in Figure $7 A$ and summarized in Table 1 . In the presence of $0.1 \mathrm{mM} \mathrm{Mg}^{2+}$, $I_{\text {CAN }}$ exhibited a larger peak amplitude than that previously observed with physiological $\mathrm{Mg}^{2+}$ concentration; its negative and positive conductances were nearly identical, and consequently its $I / V$ relation was linear. When the external $\mathrm{Mg}^{2+}$ concentration was raised from 0.1 to $2 \mathrm{~mm}$, we observed a significant decrease of the peak amplitude of $I_{\mathrm{CAN}}$ associated with a significant reduction of the negative conductance $(-58.8 \pm 3.7 \% ; p=0.0001)$. The positive conductance was unchanged, leading to a nonlinear $I / V$ curve. The reversal potential of $I_{\mathrm{CAN}}$ in $2 \mathrm{mM} \mathrm{Mg}^{2+}$ was similar to that observed in $0.1 \mathrm{~mm} \mathrm{Mg}^{2+}$. When the external $\mathrm{Mg}^{2+}$ concentration was raised from 2 to $6-10 \mathrm{~mm}$, the peak amplitude and the negative conductance of $I_{\mathrm{CAN}}$ were decreased further, 
A

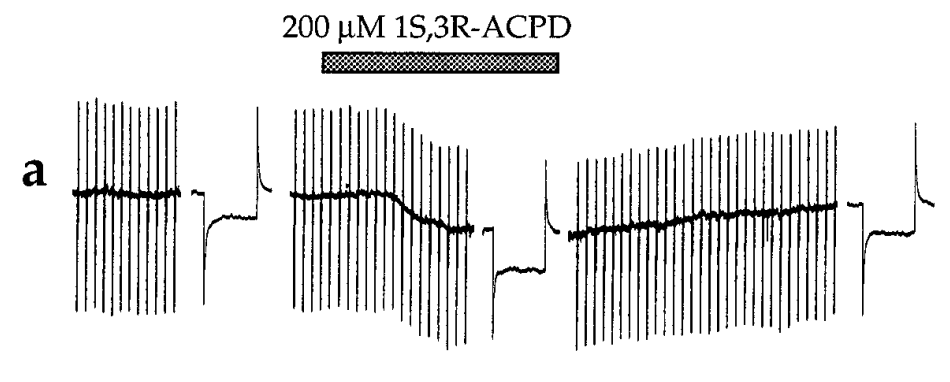

$200 \mu \mathrm{M} 1 \mathrm{~S}, 3 \mathrm{R}-\mathrm{ACPD}$

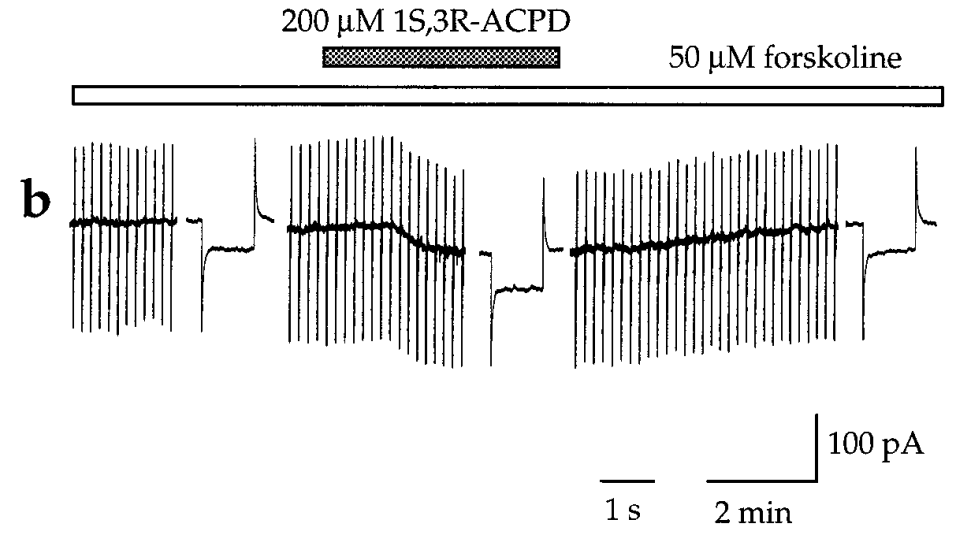

B

- 1S,3R-ACPD

$\Delta$ forskoline

o forskoline + 1S,3R-ACPD

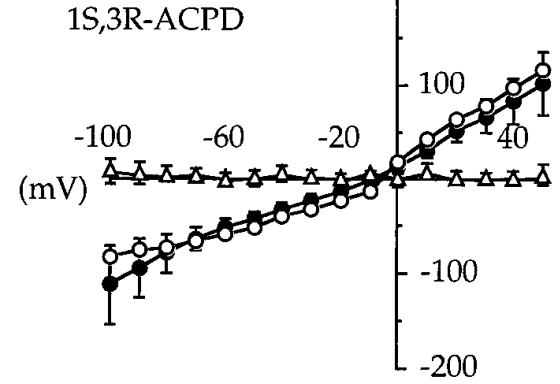

$(\mathrm{pA})$

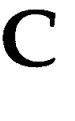

- carbachol

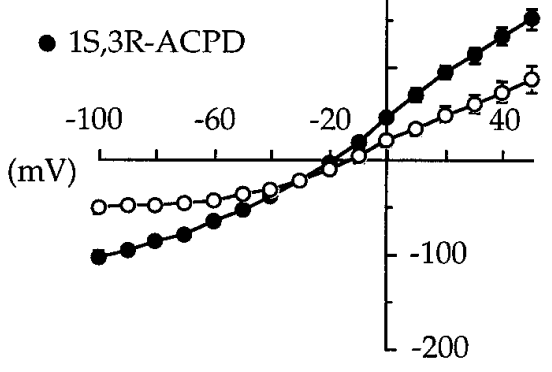

(pA)

Figure 6. $I_{\mathrm{CAN}}$ induced by $1 S, 3 R$-ACPD is not regulated by forskolin, an activator of adenylyl cyclase, and also can be induced by carbachol, a selective agonist of muscarinic receptors. $A$, Membrane current and conductance changes evoked in the same cell by two successive applications of $1 S, 3 R$-ACPD $\left(200 \mu \mathrm{M}, 2 \mathrm{~min}, V_{\mathrm{H}}=-60 \mathrm{mV}\right)$ in the absence $(a)$ and the presence $(b)$ of forskolin $(50 \mu \mathrm{M}$; added at least 10 min before the second application of $1 S, 3 R$-ACPD). $B$, Mean $I / V$ relations of the forskolin-induced currents $(\triangle)$ and of $1 S, 3 R$-ACPD-induced currents in control $(\bullet)$ and in the presence of forskolin $(\bigcirc)(n=8$; paired data). Note that forskolin itself did not induce any current and that the $I / V$ relations of $1 S, 3 R$-ACPD-induced currents in the absence and in the presence of forskolin are very similar (reversal potential, slope conductance; but see also Table 1 ). $C$, Mean $I / V$ relations of the carbachol-induced $(\bigcirc ; n=9)$ and $1 S, 3 R$-ACPD-induced currents $(\mathbf{O} ; n=55)$. Note that the carbachol- and $1 S, 3 R$-ACPD-induced CAN currents are qualitatively similar (same reversal potential and similar $I / V$ relations, despite the smaller amplitude of the carbachol-induced current; but see also Table 1).

but the positive conductance also was strongly reduced, and the reversal potential was shifted to a more positive value.

Thus, as for NMDA and cyclic nucleotide-gated currents, there is a voltage-dependent regulation of the CAN current by physiological external $\mathrm{Mg}^{2+}$ concentrations (between 1 and $2 \mathrm{~mm}$ ) at negative membrane potentials. Higher external $\mathrm{Mg}^{2+}$ concentration also shifted the reversal potential to more positive values and reduced CAN current at positive membrane potentials.

As for NMDA currents and cyclic nucleotide-gated currents (Ascher and Nowak, 1988; Mayer et al., 1989; Zufall et al., 1994), other divalent cations such as $\mathrm{Cd}^{2+}$ and $\mathrm{Zn}^{2+}$ also modulate $I_{\mathrm{CAN}}$. In the presence of $200 \mu \mathrm{M}$ of external $\mathrm{Cd}^{2+}$ the peak amplitude of $I_{\text {CAN }}$ was reduced significantly, and its reversal potential shifted to more positive values; both negative and positive conductances were strongly reduced ( $n=14$; Fig. $7 B$, Table 1). Similarly, in the presence of $200 \mu \mathrm{M}$ of external $\mathrm{Zn}^{2+}$ peak amplitude of $I_{\text {CAN }}$ was reduced, and its reversal potential shifted to more positive values. As with $\mathrm{Cd}^{2+}$ and high concentrations of $\mathrm{Mg}^{2+}$, both negative and positive conductances were strongly reduced by $\mathrm{Zn}^{2+}(n=12$; Fig. $7 C$, Table 1$)$.
In conclusion, external divalent cations regulate the CAN current by reducing its slope conductance. Their effects can be classified in two groups: the voltage-dependent blockers, such as $\mathrm{Mg}^{2+}$ (at physiological concentrations), and the non- (or weak) voltage-dependent blockers, such as $\mathrm{Cd}^{2+}$ and $\mathrm{Zn}^{2+}$ (or high concentrations of $\mathrm{Mg}^{2+}$ ).

\section{$I_{\text {CAN }}$ can be evoked synaptically}

We determined the conditions required for synaptic activation of $I_{\text {CAN }}$ to elucidate its possible role in synaptic transmission. In these experiments the CA1 region was isolated surgically from CA3. Synaptic responses were evoked by a bipolar stimulating electrode placed in the stratum radiatum or at the border between stratum radiatum and stratum lacunosum moleculare and recorded in the presence of $\mathrm{K}^{+}$channel blockers. Low-frequency stimulations $(0.05 \mathrm{~Hz})$ evoked postsynaptic responses (Fig. $8 A$ ), which were abolished completely by bicuculline, CNQX, and DL-APV (medium B; see Materials and Methods) (Fig. 8A-b, $A-c$ ). However, HFS $(25-100 \mathrm{~Hz}, 1 \mathrm{sec})$ evoked a slow inward current that was maximal at the frequency of $100 \mathrm{~Hz}$ (as illustrated in Fig. 

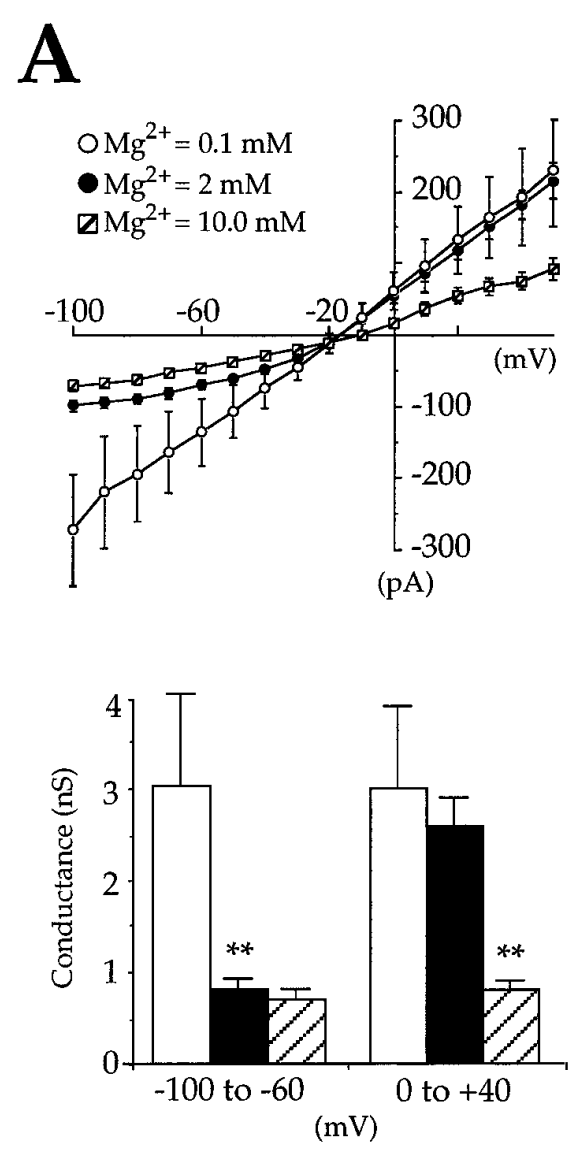

B
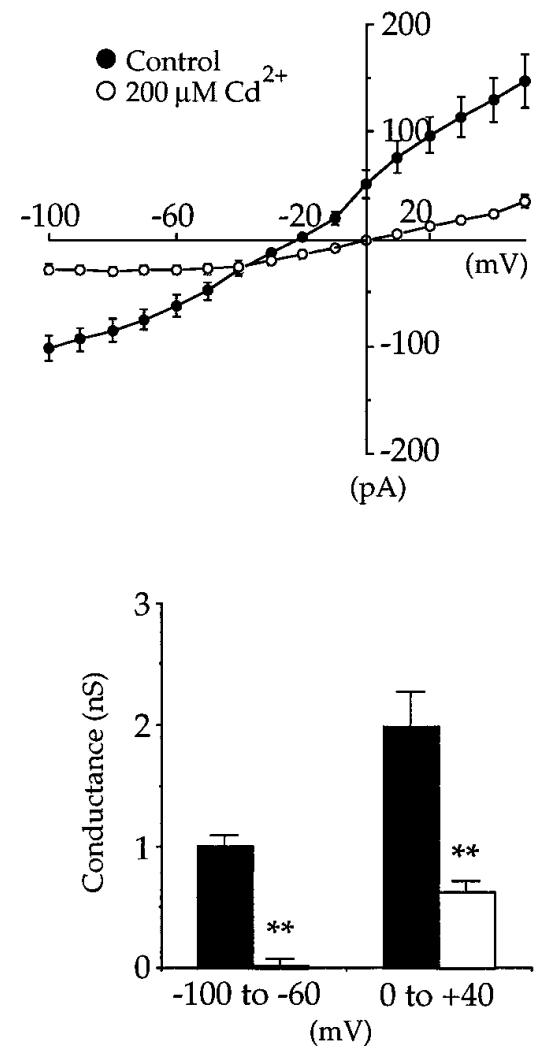
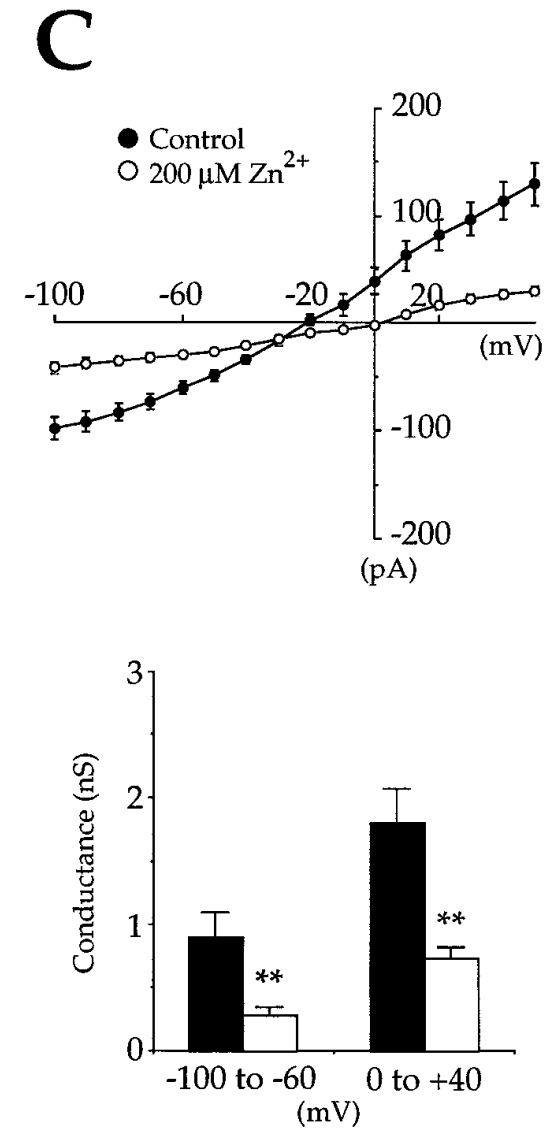

Figure 7. The divalent cation magnesium induces a voltage-dependent block, whereas divalent cations cadmium and zinc induce a voltage-independent block of CAN currents produced by $1 S, 3 R$-ACPD. $A$, Top, Mean $I / V$ relations of CAN currents produced by $1 S, 3 R-A C P D\left(200 \mu \mathrm{M}, 2 \mathrm{~min}, V_{\mathrm{H}}=-60\right.$ $\mathrm{mV}$ ) in the presence of three different magnesium concentrations: $0.1 \mathrm{mM}$ (open circles), $2 \mathrm{mM}$ ( filled circles), and $10 \mathrm{~mm}($ barred squares) $(n=7 ;$ paired data). Bottom, Mean conductances of the $I / V$ relations obtained in $A$, top, illustrating the decrease of conductance induced at negative potentials by increasing the extracellular magnesium concentration from 0.1 (open column) to $2 \mathrm{~mm}$ ( filled column) and the decrease of conductance induced at all potentials by increasing magnesium concentration from $2 \mathrm{mM}$ ( filled column) to $10 \mathrm{~mm}$ (barred column) $(n=7$; paired data; see also Table 1 ). The 2 mM condition was compared with the $0.1 \mathrm{mM}$ and then with the $10 \mathrm{~mm}$ condition. In this and the following figures, the statistical significance was assessed by paired $t$ test analysis $\left({ }^{*} p<0.05 ;{ }^{* *} p<0.01\right) . B$, Top, Mean $I / V$ relations of CAN currents produced by two successive applications of $1 S, 3 R$-ACPD $\left(200 \mu \mathrm{M}, 2 \mathrm{~min}, V_{\mathrm{H}}=-60 \mathrm{mV}\right)$ in the absence ( filled circles) and in the presence (open circles) of cadmium in the superfusing medium (200 $\mu \mathrm{M}$ at least $10 \mathrm{~min}$ before the second application of $1 S, 3 R$-ACPD) $(n=14$; paired data). Bottom, Mean conductances of the $I / V$ relations obtained in $B$, top, illustrating the decrease of conductance induced at all potentials by cadmium ( $200 \mu \mathrm{M}, n=14$; paired data; see also Table 1). $C$, Top, Mean $I / V$ relations of CAN currents produced by two successive applications of $1 S, 3 R$-ACPD $\left(200 \mu \mathrm{M}, 2 \mathrm{~min}, V_{\mathrm{H}}=-60 \mathrm{mV}\right)$ in the absence ( filled circles) and in the presence (open circles) of zinc in the superfusing medium $(200 \mu \mathrm{M})$ at least $10 \mathrm{~min}$ before the second application of $1 S, 3 R$-ACPD $(n=12 ;$ paired data). Bottom, Mean conductances of the $I / V$ relations obtained in $C$, top, illustrating the decrease of conductance induced at all potentials by zinc (200 $\mu \mathrm{M}$, $n=12$; paired data; see also Table 1).

$8 B-a)$. The current evoked by a $100 \mathrm{~Hz}$ HFS had a peak amplitude of $-42.9 \pm 3.5 \mathrm{pA}\left(V_{\mathrm{H}}=-60 \mathrm{mV} ; n=36\right)$ and a total duration of $11 \pm 1.3 \mathrm{sec}(n=36)$. The amplitude of this postsynaptic current was dependent on the frequency of stimulation (Fig. $8 B-a$ ), the stimulus intensity (Fig. $8 B-c$ ), and the duration of the HFS (Fig. $8 B-b$ ), suggesting its dependence on the level of transmitter release. Furthermore, this current was blocked completely by bath application of TTX $(1 \mu \mathrm{M})$, confirming its synaptic origin ( $n=5$; Fig. 9A-a,A-c). The voltage dependence of synaptically evoked currents was studied using ramp voltage commands applied at the peak amplitude of the evoked response. To avoid the voltage-dependent activation of calcium channels, we limited the ramp voltage commands to negative potentials $(-20 \mathrm{mV}$ to -100 $\mathrm{mV}$, ramp B; see Materials and Methods). The recorded synaptically evoked current showed a reversal potential of $-22.8 \pm 8.2$ $\mathrm{mV}$ (close to the reversal potential of $\left.I_{\mathrm{ACPD}}\right)$ and a conductance of $0.7 \pm 0.11 \mathrm{nS}$ (calculated between -100 and $-60 \mathrm{mV} ; n=13$ )
(Fig. 9C). Thus HFS evoked a slow inward postsynaptic current resistant to ionotropic glutamate and GABA receptor antagonists.

Previous studies have described slow excitatory synaptic responses mediated by muscarinic receptors in CA1 and activated by HFS (Cole and Nicoll, 1984; Madison et al., 1987). Therefore, we tested the ability of the muscarinic receptor antagonist atropine to block the HFS-evoked response. In five of five cells, atropine (up to $20 \mu \mathrm{M}$ ) changed neither the peak amplitude $(-2.2 \pm 2.2 \%$; paired data; $p=0.2)$ nor the duration $(-8.2 \pm$ $3.4 \%$; paired data; $p=0.09$ ) of the response (Fig. 9A-a, $A-b$ ).

To study the possible activation of the synaptically evoked inward current by nonionotropic glutamate receptors, we tested its sensitivity to the glutamate uptake inhibitor DHK (Watkins and Evans, 1981). As shown in Figure 9B, bath application of DHK (250 to $500 \mu \mathrm{M}$ for $15 \mathrm{~min}$ ) significantly increased the duration of the HFS-evoked synaptic current (by $120 \pm 18.5 \%$; 


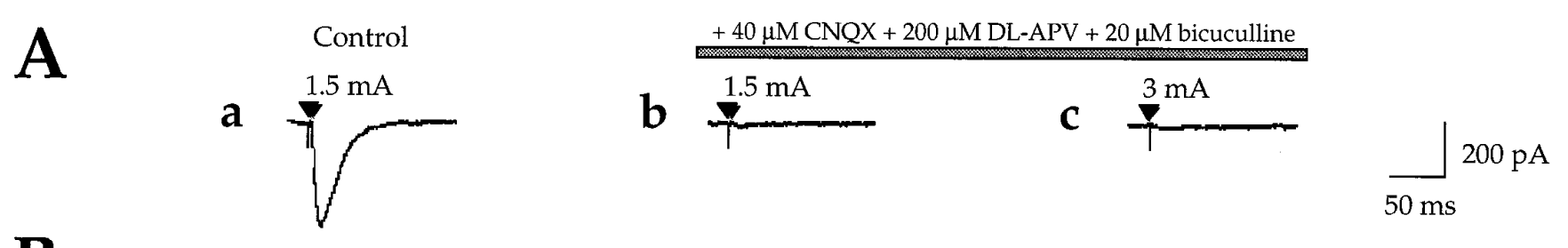

B
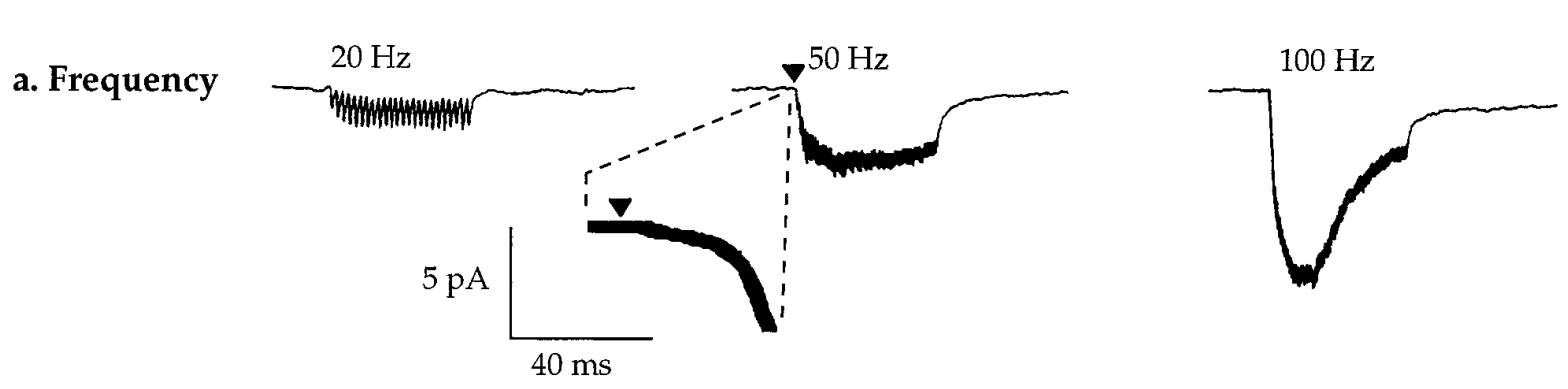

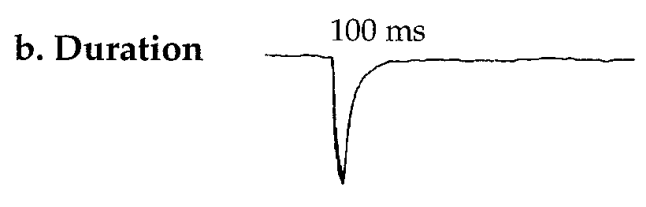

c. Intensity

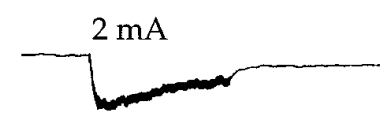

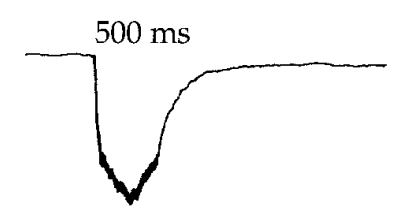
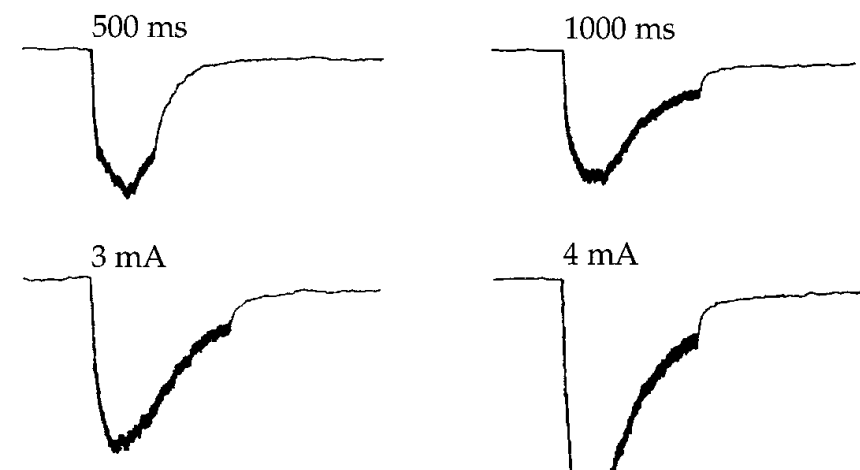

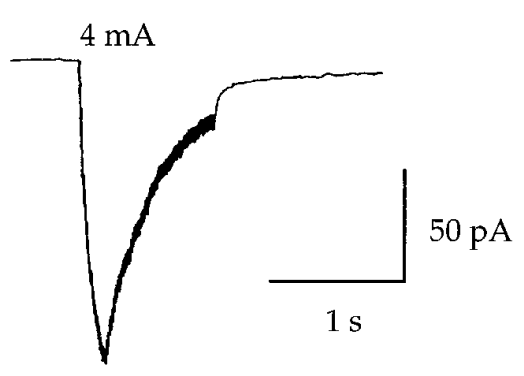

Figure 8. High-frequency stimulation (HFS) evoked a slow inward postsynaptic current resistant to ionotropic glutamate (and GABA A $_{\text {) }}$ receptor antagonists. $A$, Postsynaptic response evoked in a CA1 pyramidal neuron $\left(V_{\mathrm{H}}=-60 \mathrm{mV}\right)$ by a single shock stimulation of 1.5 and $3 \mathrm{~mA}(60 \mu \mathrm{sec})$ in control conditions $(A-a, 1.5 \mathrm{~mA})$ and in the presence of CNQX $(40 \mu \mathrm{M})$, DL-APV $(200 \mu \mathrm{M})$, and bicuculline $(20 \mu \mathrm{M})$ containing superfusion medium $\mathrm{B}$ (see Materials and Methods) $(A-b, 1.5 \mathrm{~mA} ; A-c, 3 \mathrm{~mA})$. Note that the response to a single shock stimulation is blocked by the ionotropic glutamate and GABA $\mathrm{A}_{\mathrm{A}}$ antagonists. $B$, Slow inward postsynaptic currents evoked as a function of HFS parameters in the presence of superfusion medium B (as in $A-b, A-c$; see Materials and Methods). $B$ - $a$, Slow inward postsynaptic currents evoked by HFS ( $1 \mathrm{sec}, 3 \mathrm{~mA})$ with frequencies of 20,50 , and $100 \mathrm{~Hz}$. Inset, Illustration of the onset of the response to tetanic stimulation at an expanded time scale. $B$ - $b$, Slow inward postsynaptic currents evoked by HFS $(100 \mathrm{~Hz}, 3 \mathrm{~mA})$ with duration of 100,500 , and $1000 \mathrm{msec}$. $B-c$, Slow inward postsynaptic currents evoked by HFS $(1 \mathrm{sec}, 100 \mathrm{~Hz})$ with stimulus intensities of 2,3 , and $4 \mathrm{~mA}$. Note that the response to a single shock stimulation, even at high intensity $(3 \mathrm{~mA}, 60 \mu$ sec $)$, is blocked by ionotropic glutamate and $\mathrm{GABA}_{\mathrm{A}}$ antagonists, whereas in the same conditions the same stimulus delivered at high frequency $(50-100 \mathrm{~Hz}, 1 \mathrm{sec})$ evokes a slow inward postsynaptic current.

$n=5, p=0.0002$; paired data). DHK also slightly increased the peak amplitude of the current in two of the five cells. Thus, in CA1 pyramidal cells HFS evoked a nonionotropic glutamatemediated excitatory postsynaptic current.

As shown for the $1 S, 3 R$-ACPD-evoked CAN current, the synaptically evoked current also involves $\mathrm{Ca}^{2+}$ - and G-proteindependent processes. In the presence of BAPTA, GDP $\beta$, or GTP $\gamma \mathrm{S}$ added to the pipette solution, the first responses evoked by the HFS within the $5 \mathrm{~min}$ after the passage to whole-cell configuration were similar to the responses evoked in the absence of BAPTA, GDP $\beta$ S (Fig. $10 A-a, B-a$, respectively), or GTP $\gamma \mathrm{S}$ (data not shown). After 20 min of cell dialysis with BAPTA (20 mM; $n=5$; Fig. $10 A-b)$ or GDP $\beta S$ (500 $\mu \mathrm{M} ; n=7$; Fig. $10 B-b)$, a second HFS failed to evoked a response. With GTP $\gamma \mathrm{S}$, after 20 min of cell dialysis the first response evoked by HFS was signif- icantly longer in four of six cells $(29 \pm 3.1 \mathrm{vs} 11 \pm 1.3 \mathrm{sec}$ in control, $p=0.001$ ) and irreversible in the two other cells (Fig. $10 C$ - $a$ ); subsequent HFS-evoked responses were nearly abolished (Fig. 10C-b).

Therefore HFS generates a mGluRs-dependent slow inward current that is triggered by a rise in $\left[\mathrm{Ca}^{2+}\right]_{i}$, mediated by G-proteins. This current exhibit properties of a synaptic $I_{\mathrm{CAN}}$.

\section{DISCUSSION}

The present report describes a slow nonselective cationic current $\left(I_{\mathrm{CAN}}\right)$ triggered by a $\left[\mathrm{Ca}^{2+}\right]_{\mathrm{i}}$ rise, generated by glutamate acting on group I mGluRs via a G-protein-dependent process. It provides the first characterization in the mammalian CNS of a synaptic $I_{\text {CAN }}$ generated by HFS. The presence of a mGluR- 


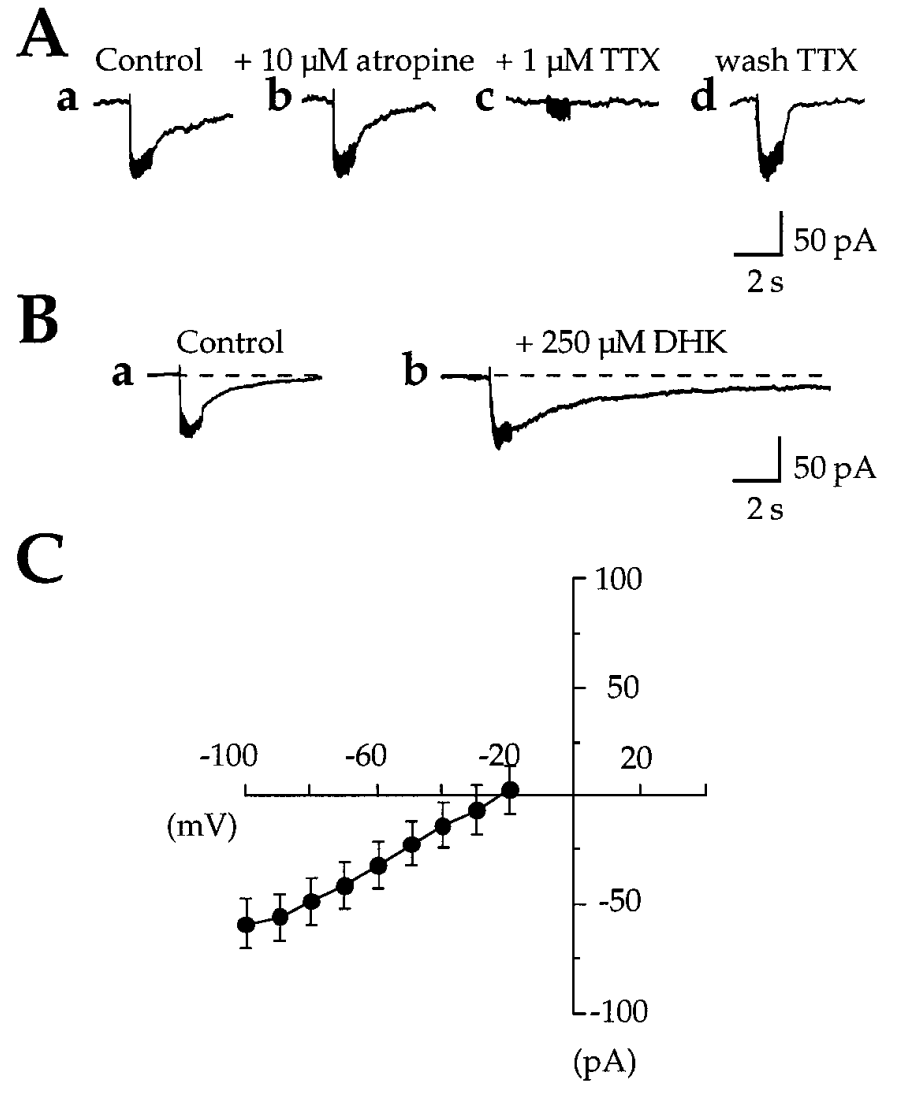

Figure 9. HFS stimuli evoked a nonionotropic glutamate-mediated excitatory postsynaptic current. $A$, Slow inward postsynaptic currents evoked in the same cell by four successive HFS $(1 \mathrm{sec}, 100 \mathrm{~Hz}, 3 \mathrm{~mA})$ and recorded in medium B (see Materials and Methods): in control conditions $(a)$, in the presence of the muscarinic receptor antagonist atropine $(b)(10$ $\mu \mathrm{M})$ at least $10 \mathrm{~min}$ before the second HFS, in the presence of tetrodotoxin $(c)(T T X, 1 \mu \mathrm{M})$ after a $10 \mathrm{~min}$ wash of atropine and at least $10 \mathrm{~min}$ before the third HFS, and back in control conditions after a 30 min wash of $T T X(d)(n=5$; paired data). Note that atropine did not change the peak amplitude or the duration of the response, which was blocked completely by $T T X$ and recovered with the wash of $T T X$. B, Slow inward postsynaptic currents evoked in the same cell by two successive HFS (1 sec, $100 \mathrm{~Hz}, 3 \mathrm{~mA}$ ): in the absence $(a)$ and in the presence of the glutamate uptake inhibitor dihydrokainic acid $(b)(D H K, 250 \mu \mathrm{M})$ added at least $15 \mathrm{~min}$ before the second HFS. Note that $D H K$ significantly increased the duration of the HFS-evoked synaptic current. $C$, Mean $I / V$ relations of the slow inward postsynaptic currents evoked by HFS (ramp command $\mathrm{B}$; see Materials and Methods) $(n=13)$. Note that this HFS-induced current and the $1 S, 3 R$-ACPD-induced CAN current (see Fig. $1 E$ ) have qualitatively similar mean $I / V$ relations (same reversal potential and similar shape, despite the smaller amplitude of the HFSinduced current).

mediated $I_{\mathrm{CAN}}$ in the CNS has several important physiological implications.

\section{Properties of $I_{\text {CAN }}$ evoked by $1 S, 3 R-A C P D$ in CA1 pyramidal neurons}

In the CNS several studies have described an inward current associated with an increase in membrane conductance, mediated by exogenous activation of glutamate metabotropic receptors, in the presence of $\mathrm{K}^{+}$channel blockers (Glaum and Miller, 1992; Staub et al., 1992; Mercuri et al., 1993). A nonselective cationic current induced by $1 S, 3 R$-ACPD was, however, first described in CA1 pyramidal neurons of adult rat hippocampal slices by Crépel et al. (1994). In that work the authors characterized a $\mathrm{Ca}^{2+}$. dependent, weakly temperature-sensitive, nonselective cationic current corresponding to the CAN cationic current defined in invertebrate preparations (Swandulla and Partridge, 1990). The $1 S, 3 R$-ACPD-induced current described in the present study using whole-cell patch-clamp recordings has similar features to those currents described above, namely in terms of nonselectivity for monovalent cations, reversal potential, and dependence on $\left[\mathrm{Ca}^{2+}\right]_{\mathrm{i}}$.

CAN channels have been found principally to be permeable to $\mathrm{Na}^{+}$and $\mathrm{K}^{+}$(for review, see Swandulla and Partridge, 1990) and occasionally to $\mathrm{Cs}^{+}$ions (Yellen, 1982; Lipton, 1986; Simmoneau et al., 1987; Teulon et al., 1987). In our experimental conditions we have observed that the reversal potential of the CAN current was more negative than that expected from the Nernst equation. We suspect that it may be attributable to a better permeability of CAN channels for $\mathrm{Cs}^{+}$, which will tend to displace the reversal potential to more negative values. Using the Goldman-HodgkinKatz equation (Goldman, 1943; Hodgkin and Katz, 1949), we estimated, under our experimental conditions, a permeability ratio $P_{\mathrm{Cs}}{ }^{+} / P_{\mathrm{Na}}{ }^{+}=3$.

Additionally, hippocampal $I_{\mathrm{CAN}}$ is modulated by the external divalent cations $\mathrm{Mg}^{2+}, \mathrm{Cd}^{2+}$, and $\mathrm{Zn}^{2+}$ via two pathways: a voltage-dependent block $\left(\mathrm{Mg}^{2+}\right)$ and a voltage-independent one $\left(\mathrm{Cd}^{2+}, \mathrm{Zn}^{2+}\right)$. These properties, and in particular the voltagedependent block by external $\mathrm{Mg}^{2+}$, are reminiscent of other types of cationic channels, including NMDA channels (Ascher and Nowak, 1988; Mayer et al., 1989), cyclic nucleotide-gated channels (for review, see Zufall et al., 1994), and a nonselective cationic conductance recently described in CA3 pyramidal cells (Caeser et al., 1993; Guérineau et al., 1995). The voltagedependent modulation of $I_{\mathrm{CAN}}$ suggests that CAN channels are regulated directly by external $\mathrm{Mg}^{2+}$. It is not clear, however, whether this property will enable mGluRs to exert a coincident detection property that typically is associated with NMDARs. Future studies will have to determine the consequences of this feature.

\section{$I_{\text {CAN }}$ is generated via a G-protein-dependent process by group I mGluRs}

Previous studies have shown clearly that mGluRs are linked to phospholipase $\mathrm{C}$ and adenylyl cyclase via G-proteins (for review, see Schoepp and Conn, 1993; Pin and Duvoisin, 1995). As expected, we found that activation of $I_{\mathrm{CAN}}$ by $1 S, 3 R$-ACPD involved a G-protein-dependent process. In the presence of GTP $\gamma \mathrm{S}$, which blocks the G-protein in its activated state, $1 S, 3 R$ ACPD irreversibly activated $I_{\mathrm{CAN}}$, whereas in the presence of GDP $\beta S$, which blocks the G-protein in its inactivated state, $1 S, 3 R$-ACPD did not evoke any current. These two complementary results clearly demonstrate the role of a G-protein-dependent process in the $1 S, 3 R$-ACPD-induced $I_{\mathrm{CAN}}$ and further confirm that this current is activated by mGluRs via a metabotropic pathway (Sladeczek et al., 1985; Sugiyama et al., 1987).

Previous immunohistological studies have shown that group I mGluRs are expressed prominently in the CA1 region of hippocampus (Abe et al., 1992; Shigemoto et al., 1993; Luján et al., 1996), whereas group II mGluRs are not (Ohishi et al., 1994). In keeping with this (also see Gereau and Conn, 1995), in CA1 pyramidal neurons $I_{\mathrm{CAN}}$ is mediated by group I mGluRs, which are known to be positively linked to the $\mathrm{IP}_{3}$ production pathway and do not implicate a change of adenylyl cyclase activity, because (1) DHPG, a selective agonist of group I mGluRs (mGluR 1 and 5) (Ito et al., 1992; Schoepp et al., 1994), generates a current 
A

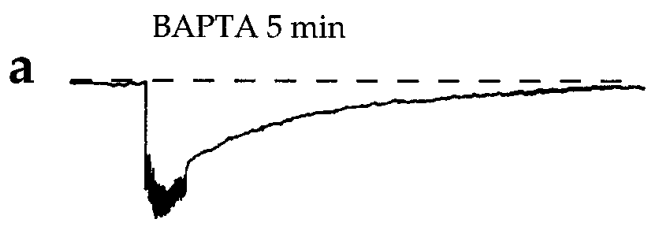

B

a

a

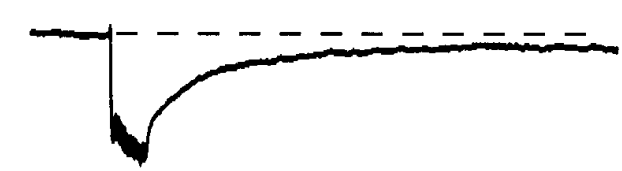

GDPßS 5 min

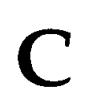

a
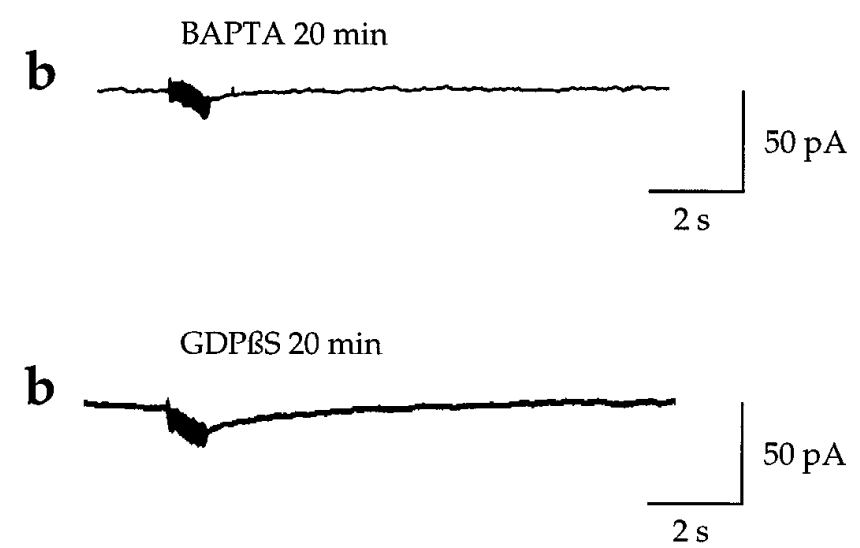

GTP $\gamma 20 \mathrm{~min}$

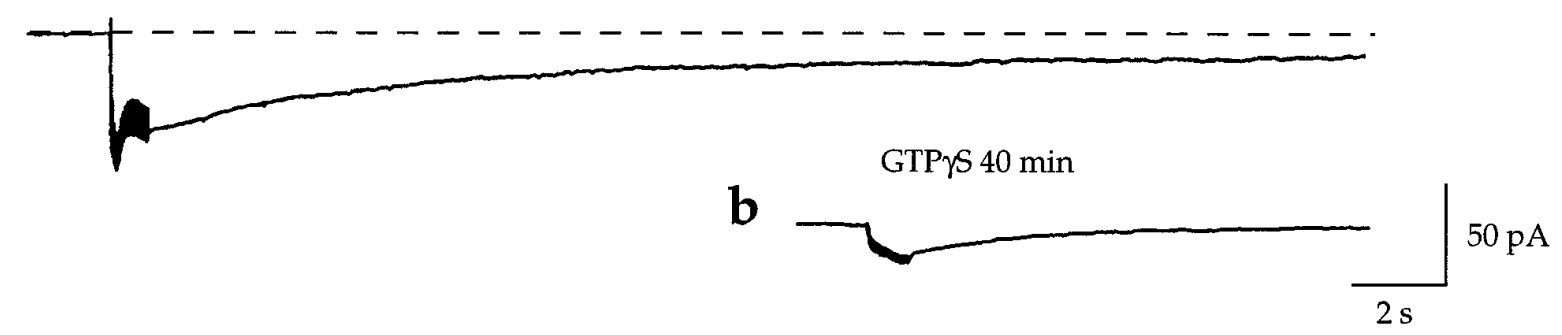

Figure 10. HFS-generated nonionotropic slow inward currents are triggered by a rise in $\left[\mathrm{Ca}^{2+}\right]_{\mathrm{i}}$ and mediated by G-proteins. $A$, Slow inward postsynaptic currents evoked in the same cell by two successive HFS (1 sec, $100 \mathrm{~Hz}, 3 \mathrm{~mA})$ in the presence of the calcium chelator BAPTA (20 mM) in the CsGlu pipette solution within the $5 \mathrm{~min}$ after the passage to whole cell $(a)$ and after $20 \mathrm{~min}$ of cell dialysis $(b)(n=5$; paired data). $B$, Slow inward postsynaptic currents evoked in the same cell by two successive HFS ( $1 \mathrm{sec}, 100 \mathrm{~Hz}, 3 \mathrm{~mA})$ in the presence of the G-protein inhibitor GDP $\beta$ S (500 $\mu \mathrm{M}$ ) in the CsGlu pipette solution within the $5 \mathrm{~min}$ after the passage to whole cell $(a)$ and after $20 \mathrm{~min}$ of cell dialysis $(b)(n=7$; paired data). Note that in the presence of BAPTA or GDP $\beta$ S a second HFS failed to evoked any subsequent response. $C$, Slow inward postsynaptic currents evoked in the same cell by two successive HFS ( $1 \mathrm{sec}, 100 \mathrm{~Hz}, 3 \mathrm{~mA})$ in the presence of the nonhydrolyzable analog of GTP, GTP $\gamma \mathrm{S}(500 \mu \mathrm{M})$, in the CsGlu pipette solution after $20(a)$ and $40 \mathrm{~min}(b)$ of cell dialysis $(n=6$; paired data). Note that in the presence of GTP $\gamma \mathrm{S}$ the first response evoked by HFS is significantly longer (even irreversible) than in control (see Figs. $6 B, 7 A-a, B-a)$ and that subsequent HFS-evoked responses are nearly abolished (b).

identical to that evoked by $1 S, 3 R$-ACPD; (2) DCG IV and L-AP4, selective agonists of group II and III mGluRs, respectively, which are both negatively linked to the adenylyl cyclase pathway (Tanabe et al., 1992, 1993), do not evoke $I_{\mathrm{CAN}}$; and (3) forskolin, an activator of adenylyl cyclase, does not modify $I_{\mathrm{CAN}}$.

Because mGluR5s are expressed prominently in CA1 pyramidal neurons (Abe et al., 1992; Shigemoto et al., 1993; Luján et al., 1996), whereas mGluR1 subtypes are localized in CA1 interneurons (Martin et al., 1992; Baude et al., 1993; Luján et al., 1996), the CAN current described in the present report probably is mediated by mGluR5. In addition, the absence of effect of MCPG provides further evidence that $I_{\mathrm{CAN}}$ involved the activation of mGluR5 and not mGluR1, because MCPG antagonizes mGluR1mediated, but not mGluR5-mediated, responses (Joly et al., 1995) and has no effect on CA1 pyramidal neurons (Chinestra et al., 1993; Izumi and Zorumski, 1994; Manzoni et al., 1994; Selig et al., 1995) (but see Bashir et al., 1993; Brown et al., 1994). Direct evidence in support of this must await the development of a selective mGluR5 antagonist.

Our pharmacological study shows that $I_{\mathrm{CAN}}$ is evoked by group I mGluRs, which are known to be positively linked to the $\mathrm{IP}_{3}$ production pathway. We then suggest that $I_{\mathrm{CAN}}$ can be activated by other receptors linked to the same messenger pathway. In keeping with this and in agreement with previous data (Shen and North, 1992; Colino and Halliwell, 1993; Fraser and MacVicar,
1996), we found that activation of muscarinic receptors, linked to the $\mathrm{IP}_{3}$ production pathway in the CA1 area (Fisher et al., 1983; Dutar and Nicoll, 1988), also activates a current with the same feature as $I_{\mathrm{CAN}}$.

\section{Properties and functional significance of a synaptic ICAN generated by mGluRs}

Several lines of evidence show that the current activated synaptically by a brief HFS of afferent fibers in the stratum lacunosum moleculare-radiatum area was similar to the $I_{\mathrm{CAN}}$ evoked by exogenous application of $1 S, 3 R$-ACPD. HFS induced an excitatory postsynaptic response composed of a fast ionotropic component and a slow metabotropic component that persist in the presence of ionotropic glutamate and $\mathrm{GABA}_{\mathrm{A}}$ receptor antagonists. This slow inward current increases in amplitude and duration in the presence of glutamate uptake inhibitor and is not blocked by muscarinic receptor antagonists. In addition, it is blocked by the $\mathrm{Ca}^{2+}$ chelating agent BAPTA and by G-protein inhibitors (GTP $\gamma \mathrm{S}$ and GDP $\beta \mathrm{S})$, and it displayed a reversal potential similar to that of the $1 S, 3 R$-ACPD-activated $I_{\mathrm{CAN}}$. Taken together, these data strongly suggest that this slow synaptic inward current is generated, as $I_{\mathrm{ACPD}}$, through mGluRs via G-protein- and $\mathrm{Ca}^{2+}$-dependent activation of an excitatory postsynaptic nonselective cationic current $I_{\mathrm{CAN}}$. Although synaptic currents evoked in the presence of ionotropic glutamate re- 
ceptor antagonists have been reported in earlier studies (Charpak and Gähwiler, 1991; Glaum and Miller, 1992; Batchelor et al., 1994; Pozzo Miller et al., 1995; Batchelor and Garthwaite, 1997), to the best of our knowledge the present report is the first description of a synaptically triggered CAN current in mammalian CNS neurons. This synaptic $I_{\text {CAN }}$ exhibited a slow kinetic and may mediate a long-lasting excitation outlasting the action of most voltage-dependent ionic currents (as NMDA, for instance). This property is in keeping with the specific slow kinetics of the CAN single channel observed in several invertebrate preparations (for review, see Swandulla and Partridge, 1990). In the present study the synaptic $I_{\text {CAN }}$ required relatively strong HFS to be generated. This is likely the consequence of the perisynaptic location of mGluR5 in CA1 pyramidal neurons (Baude et al., 1993; Luján et al., 1996). An accumulation of glutamate in the synaptic cleft and a "spillover" may be required to reach the perisynaptic receptors and trigger a mGluR-mediated response. Therefore, at least in CA1 pyramidal neurons $I_{\mathrm{CAN}}$ probably does not participate in ongoing spontaneous activity; a different situation may prevail in interneurons (see Miles and Poncer, 1993).

The demonstration of a synaptically activated CAN current mediated by mGluRs adds a novel facet to the pleiotropic repertoire of modulations exerted by glutamate metabotropic receptors in the CNS. In the hippocampus, activation of cationic currents through metabotropic receptors generates long-lasting plateau potentials (Fraser and MacVicar, 1996) and provides the basis for synchronized activities (Yaari and Jensen, 1989; Miles and Poncer, 1993; Bianchi and Wong, 1995). The synaptically activated $I_{\mathrm{CAN}}$ described in the present report may play an important role in synaptic integration, notably as frequency sensors, in regard to its strong frequency dependence. Interestingly, Batchelor and Garthwaite (1997) recently have described, in the cerebellum, an inward current generated through mGluRs that integrates temporally dispersed signals from two different inputs. It will be important to establish whether this synaptic response is mediated by a CAN current.

We suggest that CAN currents activated in the hippocampus, presumably as a consequence of an important accumulation of glutamate, may contribute not only to the normal physiological functions, such as the neuronal plasticity, but also to the longlasting excitotoxic depolarizations observed in pathological conditions, such as epilepsy or ischemia.

\section{REFERENCES}

Abe T, Sugihara H, Nawa H, Shigemoto R, Mizuno N, Nakanishi S (1992) Molecular characterization of a novel metabotropic glutamate receptor mGluR5 coupled to inositol phosphate $/ \mathrm{Ca}^{2+}$ signal transduction. J Biol Chem 19:13361-13368.

Ascher P, Nowak L (1988) The role of divalent cations in the $N$-methylD-aspartate responses of mouse central neurones in culture. J Physiol (Lond) 399:247-266.

Bashir ZI, Bortolotto ZA, Davies CH, Beretta N, Irving AJ, Seal AJ, Henley JM, Jane DE, Watkins JC, Collingridge GL (1993) Induction of LTP in the hippocampus needs synaptic activation of glutamate receptors. Nature 363:347-350.

Batchelor AM, Garthwaite J (1997) Frequency detection and temporally dispersed synaptic signal association through a metabotropic glutamate receptor pathway. Nature 385:74-77.

Batchelor AM, Madge DJ, Garthwaite J (1994) Synaptic activation of metabotropic glutamate receptors in the parallel fibre-Purkinje cell pathway in rat cerebellar slices. Neuroscience 63:911-915.

Baude A, Nusser Z, Roberts JDB, Mulvihill E, McIlhinney RAJ, Somogyi P (1993) The metabotropic glutamate receptor (mGluR1 $\alpha$ ) is concentrated at perisynaptic membrane of neuronal subpopulations as detected by immunogold reaction. Neuron 11:771-787.

Ben-Ari Y, Aniksztejn L (1995) Role of glutamate metabotropic recep- tors in long-term potentiation in the hippocampus. Semin Neurosci 7:127-135

Bianchi R, Wong RKS (1995) Excitatory synaptic potentials dependent on metabotropic glutamate receptor activation in guinea-pig hippocampal pyramidal cells. J Physiol (Lond) 487:663-676.

Brown RE, Rabe H, Reymann KG (1994) (R-S)- $\alpha$-Methyl-4-carboxyphenylglycine (MCPG) does not block theta burst-induced long-term potentiation in area CA1 of rat hippocampal slices. Neurosci Lett 170:17-21.

Caeser M, Brown DA, Gähwiler BH, Knöpfel T (1993) Characterization of a calcium-dependent current generating a slow afterdepolarization of CA3 pyramidal cells in rat hippocampal slices cultures. Eur J Neurosci 5:560-569.

Charpak S, Gähwiler BH (1991) Glutamate mediates a slow synaptic response in hippocampal slice cultures. Proc R Soc Lond [Biol] 243:221-226.

Cherubini E, Ben-Ari Y, Gho M (1987) Long-term potentiation of synaptic transmission in the hippocampus induced by a bee venom peptide. Nature 328:70-73.

Chinestra P, Aniksztejn L, Diabira D, Ben-Ari Y (1993) $(R-S)-\alpha-$ Methyl-4-carboxyphenylglycine neither prevents induction of LTP nor antagonizes metabotropic glutamate receptors in CA1 hippocampal neurons. J Neurophysiol 70:2684-2689.

Cole AE, Nicoll RA (1984) Characterization of a slow cholinergic postsynaptic potential recorded in vitro from rat hippocampal pyramidal cells. J Physiol (Lond) 352:173-188.

Colino A, Halliwell JV (1993) Carbachol potentiates Q current and activates a calcium-dependent nonspecific conductance in rat hippocampus in vitro. Eur J Neurosci 5:1198-1209.

Crépel V, Aniksztejn L, Ben-Ari Y, Hammond C (1994) Glutamate metabotropic receptors increase a $\mathrm{Ca}^{2+}$-activated nonspecific cationic current in CA1 hippocampal neurons. J Neurophysiol 72:1561-1569.

Dutar P, Nicoll RA (1988) Classification of muscarinic responses in hippocampus in terms of receptors subtypes and second messenger systems: electrophysiological studies in vitro. J Neurosci 8:4214-4224.

Eaton SA, Jane DE, Jones PLSJ, Porter RHP, Pook PC-K, Sunter DC, Udvarhelyi PM, Roberts PJ, Salt TE, Watkins JC (1993) Competitive antagonism at metabotropic glutamate receptors by $(S)$-4-carboxyphenylglycine and $(R-S)$ - $\alpha$-methyl-4-carboxyphenylglycine. Eur J Pharmacol 244:195-197.

Fisher SK, Klinger PD, Agranoff BW (1983) Muscarinic agonist binding and phospholipid turnover in brain. J Biol Chem 258:7358-7363.

Fisher SK, Figueiredo JC, Bartus RT (1984) Differential stimulation of inositol phospholipid turnover in brain by analogs of oxotremorine. J Neurochem 43:1171-1179.

Fraser DD, MacVicar BA (1996) Cholinergic-dependent plateau potential in hippocampal CA1 pyramidal neurons. J Neurosci 16:4113-4128.

Frenguelli BG, Potier B, Slater NT, Alford S, Collingridge GL (1993) Metabotropic glutamate receptors and calcium signaling in dendrites of hippocampal CA1 neurones. Neuropharmacology 32:1229-1237.

Gallagher JP, Zheng F, Shinnick-Gallhager P (1994) Long-lasting modulation of synaptic transmission by metabotropic glutamate receptors. In: The metabotropic glutamate receptors (Conn PJ, Patel J, eds), pp 173-193. Totowa, NJ: Humana.

Gereau RW, Conn PJ (1995) Role of specific metabotropic glutamate receptor subtypes in regulation of hippocampal CA1 pyramidal cell excitability. J Neurophysiol 74:122-129.

Glaum SR, Miller RJ (1992) Metabotropic glutamate receptors mediate excitatory transmission in the nucleus of the solitary tract. J Neurosci 12:2251-2258.

Goldman DE (1943) Potential, impedance, and rectification in membranes. J Gen Physiol 27:37-60.

Guérineau NC, Bossu JL, Gähwiler BH, Gerber U (1995) Activation of a nonselective cationic conductance by metabotropic glutamatergic and muscarinic agonists in CA3 pyramidal neurons of the rat hippocampus. J Neurosci 15:4395-4407.

Hodgkin AL, Katz B (1949) The effect of sodium ions on the electrical activity of the giant axon of the squid. J Physiol (Lond) 108:37-77.

Ishida M, Saitoh T, Shimamoto K, Ohfune Y, Shinozaki H (1993) A novel metabotropic glutamate receptor agonist: marked depression of monosynaptic excitation in the newborn rat isolated spinal cord. Br $\mathbf{J}$ Pharmacol 109:1169-1177.

Ito I, Kohda A, Tanabe S, Hirose E, Hayashi M, Mitsunaga S, Sugiyama H (1992) 3,5-Dihydrophenylglycine: a potent agonist of metabotropic glutamate receptors. NeuroReport 3:1013-1016. 
Izumi Y, Zorumski CF (1994) Developmental changes in the effects of metabotropic glutamate receptor antagonists on CA1 long-term potentiation in rat hippocampal slices. Neurosci Lett 176:89-92.

Jaffe DB, Brown TH (1994) Metabotropic glutamate receptor activation induces calcium waves within hippocampal dendrites. J Neurophysiol 72:471-474.

Joly C, Gomeza J, Brabet I, Curry K, Bockaert J, Pin J-P (1995) Molecular, functional, and pharmacological characterization of the metabotropic glutamate receptor type 5 splice variants: comparison with mGluR1. J Neurosci 15:3970-3981.

Kao JPY, Harootunian AT, Tsien RY (1989) Photochemically generated cytosolic calcium pulses and their detection by Fluo-3. J Biol Chem 264:8179-8184.

Leinekugel X, Tseeb V, Ben-Ari Y, Bregestovski P (1995) Synaptic $\mathrm{GABA}_{\mathrm{A}}$ activation induces $\mathrm{Ca}^{2+}$ rise in pyramidal cells and interneurons from rat neonatal hippocampal slices. J Physiol (Lond) 487:319-329.

Lipton SA (1986) Antibody activates cationic channels via second messenger $\mathrm{Ca}^{2+}$. Biochim Biophys Acta 856:59-67.

Luján R, Nusser Z, Roberts JDB, Shigemoto R, Somogyi P (1996) Perisynaptic location of metabotropic glutamate receptors mGluR1 and mGluR5 on dendrites and dendritic spines in the rat hippocampus. Eur J Neurosci 8:1488-1500.

Madison DV, Lancaster B, Nicoll RA (1987) Voltage-clamp analysis of cholinergic action in the hippocampus. J Neurosci 7:733-741.

Manzoni OJ, Weisskop MG, Nicoll RA (1994) MCPG antagonizes metabotropic glutamate receptors but not long-term potentiation in the hippocampus. Eur J Neurosci 6:1050-1054.

Martin LJ, Blackstone CD, Huganir RL, Price DL (1992) Cellular localization of a metabotropic glutamate receptor in rat brain. Neuron 9:259-270.

Mayer ML, Miller R (1990) Excitatory amino acid receptors, second messengers, and regulation of intracellular calcium in mammalian neurones. Trends Pharmacol Sci 11:254-259.

Mayer ML, Vyklicky Jr L, Westbrook GL (1989) Modulation of excitatory amino acid receptors by group IIB metal cations in cultured mouse hippocampal neurons. J Physiol (Lond) 415:329-350.

Mercuri NB, Stratta F, Calabresi P, Bernardi G (1993) Activation of metabotropic glutamate receptors induces an inward current in rat dopamine mesencephalic neurons. Neuroscience 56:399-407.

Miles R, Poncer JC (1993) Metabotropic glutamate receptors mediate a post-tetanic excitation of guinea-pig hippocampal inhibitory neurones. J Physiol (Lond) 463:461-473.

Ohishi H, Ogawa-Meguro R, Shigemoto R, Kaneko T, Nakanishi S, Mizuno N (1994) Immunohistochemical localization of metabotropic glutamate receptors, mGluR2 and mGluR3, in rat cerebellar cortex. Neuron 13:55-66.

Petrozzino JJ, Connor JA (1994) Dendritic $\mathrm{Ca}^{2+}$ accumulations and metabotropic glutamate receptor activation associated with an $\mathrm{N}$-methyl-D-aspartate receptor-independent long-term potentiation in hippocampal CA1 neurons. Hippocampus 4:546-558.

Pin JP, Duvoisin R (1995) Review: neurotransmitter receptors. I. The metabotropic glutamate receptors: structure and functions. Neuropharmacology 34:1-26.

Pozzo Miller LD, Petrozzino JJ, Connor JA (1995) G-protein-coupled receptors mediate a fast excitatory postsynaptic current in CA3 pyramidal neurons in hippocampal slices. J Neurosci 15:8320-8330.

Schoepp DD, Conn PJ (1993) Metabotropic glutamate receptors in brain function and pathology. Trends Pharmacol Sci 14:13-20.

Schoepp DD, Goldsworthy J, Johnson BG, Salhoff CR, Baker SR (1994)
3,5-Dihydrophenylglycine is a highly selective agonist for phosphoinositide-linked metabotropic glutamate receptors in the rat hippocampus. J Neurochem 63:769-772.

Segal M, Barker JL (1984) Rat hippocampal neurons in culture: potassium conductances. J Neurophysiol 51:1409-1433.

Selig DK, Lee H-K, Bear MF, Malenka RC (1995) Reexamination of the effects of MCPG on hippocampal LTP, LTD, and depotentiation. J Neurophysiol 74:1075-1082.

Shen KS, North RA (1992) Muscarine increases cation conductance and decreases potassium conductance in rat locus coeruleus neurones. J Physiol (Lond) 455:471-485.

Shigemoto R, Nomura S, Ohishi H, Sugihara H, Nakanishi S, Mizuno N (1993) Immunohistochemical localization of a metabotropic glutamate receptor, mGluR5, in the rat brain. Neurosci Lett 163:53-57.

Shirasaki T, Harata N, Akaike NJ (1994) Metabotropic glutamate response in acutely dissociated hippocampal CA1 pyramidal neurones of the rat. J Physiol (Lond) 475:439-453.

Simmoneau M, Distasi C, Tauc L, Barbin G (1987) Potassium channels in mouse neonate dorsal root ganglion cells: a patch-clamp study. Brain Res 412:224-232.

Sladeczek F, Pin JP, Recassens M, Bockaert J, Weiss S (1985) Glutamate stimulates inositol phosphate formation in striatal neurones. Nature 317:717-719.

Staub C, Vranesic I, Knöpfel T (1992) Responses to metabotropic glutamate receptor activation in cerebellar Purkinje cells: induction of an inward current. Eur J Neurosci 4:832-839.

Storm JF (1988) Temporal integration by a slowly inactivating $\mathrm{K}^{+}$current in hippocampal neurons. Nature 336:379-381.

Storm JF (1990) Potassium currents in the hippocampal pyramidal cells. Prog Brain Res 83:161-187.

Sugiyama H, Ito I, Hirono C (1987) A new type of glutamate receptor linked to inositol phospholipid metabolism. Nature 325:531-533.

Swandulla D, Partridge LD (1990) Nonspecific cation channels. In: Potassium channels (Cook NS, ed), pp 167-180. Chichester, UK: Ellis Horwood.

Tanabe Y, Masu M, Ishii T, Shigemoto R, Nakanishi S (1992) A family of metabotropic glutamate receptors. Neuron 8:169-179.

Tanabe Y, Nomura A, Masu M, Shigemoto R, Mizuno N, Nakanishi S (1993) Signal transduction, pharmacological properties, and expression patterns of two rat metabotropic glutamate receptors, mGluR3 and mGluR4. J Neurosci 13:1372-1378.

Teulon J, Paulais M, Bouthier M (1987) A Ca ${ }^{2+}$-activated cationselective channel in the basolateral membrane of the cortical thick ascending limb of Henle's loop of the mouse. Biochim Biophys Acta 905:125-132.

Thomsen C, Kristensen P, Mulvihill E, Haldeman B, Suzdak PD (1992) L-2-Amino-4-phosphonobutyrate (L-AP4) is a agonist at the type IV metabotropic glutamate receptor, which is negatively coupled to adenylate cyclase. Eur J Pharmacol 227:361-362.

Watkins JC, Evans RH (1981) Excitatory amino acid transmitters. Annu Rev Pharmacol Toxicol 21:165-204.

Yaari Y, Jensen MS (1989) Cholinergic modulation of hippocampal epileptic activity in vitro. In: Central cholinergic synaptic transmission (Frotscher M, Misgeld U, eds), pp 150-158. Basel: Birkhäuser.

Yellen G (1982) Single $\mathrm{Ca}^{2+}$-activated nonselective cation channels in neuroblastoma. Nature 296:357-359.

Zufall F, Firestein S, Shepherd GM (1994) Cyclic nucleotide-gated ion channels and sensory transduction in olfactory receptor neurons. Annu Rev Biophys Biomol Struct 23:577-607. 